\title{
Preserving for the future the - once widespread but now vanishing - knowledge on traditional pig grazing in forests and marshes (Sava-Bosut floodplain, Serbia)
}

\author{
Zsolt Molnár ${ }^{1 *}$, Klára Szabados², Alen Kiš², Jelena Marinkov³ , László Demeter ${ }^{1}$, Marianna Biró ${ }^{1}$, Kinga Öllerer ${ }^{1,4}$, \\ Krisztián Katona ${ }^{5}$, Marko Đapić ${ }^{2}$, Ranko Perić², Viktor Ulicsni ${ }^{1}$ and Dániel Babai ${ }^{6}$
}

\begin{abstract}
Background: Traditional knowledge is key for sustainability, but it is rapidly disappearing. Pig keeping in forests and marshes is an ancient, once widespread, now vanishing practice, with a major economic and ecological potential. The knowledge of pig keepers and the foraging activity of pigs are hardly documented.

Methods: We studied the knowledge of traditional pig keepers (svinjars) on wild plants and pig foraging on the Sava-Bosut forest-marsh complex in Serbia. We conducted picture-based interviews about 234 locally common and/ or salient plant species, and participatory fieldwork (11 days) and visual observation (21 days) on pig foraging.

Results: 181 wild plant species were known by svinjars and 106 taxa were consumed by pigs. Svinjars knew well and could name most regularly foraged species. 98 species were reported by svinjars as foraged and 56 as not eaten. 28 species were observed by the authors as eaten regularly, while 21 were nibbled and 17 avoided. Contradictory information on foraging was rare both among svinjars (8 species) and between svinjars and researchers (7 species); several of these species were rare. Leaves of 92, fruits or seeds of 21 and 'roots' of 20 species were reported or observed as eaten, usually with high seasonality. Svinjars were overall observant, but knew little about some less salient species (e.g. Veronica, Circaea). The most common forages (reported and/or observed) were fruits (Quercus, fleshy fruits), grasses (Agrostis, Glyceria), herbs (Ranunculus ficaria, Circaea), nutritious'roots' (Carex spp., Iris), young shrub leaves (Crataegus, Carpinus) and 'tame' plants growing in the sun (Persicaria dubia, Erigeron annuus). Traditional, now extinct pig breeds were reported as less selective and more 'knowledgeable' about plants, as they received less additional fodder. Svinjars learnt their knowledge since childhood, from community members, but long-term personal observations and everyday encounters with pigs were also important sources of knowledge.
\end{abstract}

Conclusions: A deeper understanding of pig foraging could contribute to using pigs in nature conservation management, resource management and organic farming, and to a better understanding of wild boar foraging. The knowledge of svinjars is a disappearing intangible cultural heritage of European importance. Knowledge holders deserve recognition, and legal and financial support to continue this tradition.

*Correspondence: molnar.zsolt@ecolres.hu

${ }^{1}$ Centre for Ecological Research, Institute of Ecology and Botany, Vácrátót 2163, Hungary

Full list of author information is available at the end of the article permits use, sharing, adaptation, distribution and reproduction in any medium or format, as long as you give appropriate credit to the original author(s) and the source, provide a link to the Creative Commons licence, and indicate if changes were made. The images or other third party material in this article are included in the article's Creative Commons licence, unless indicated otherwise in a credit line to the material. If material is not included in the article's Creative Commons licence and your intended use is not permitted by statutory regulation or exceeds the permitted use, you will need to obtain permission directly from the copyright holder. To view a copy of this licence, visit http://creativecommons.org/licenses/by/4.0/. The Creative Commons Public Domain Dedication waiver (http://creativeco mmons.org/publicdomain/zero/1.0/) applies to the data made available in this article, unless otherwise stated in a credit line to the data. 
Keywords: Knowledge generation, Cultural heritage, Conservation management, Sustainable use of natural resources, Foraging, Sus scrofa domestica, Wild boar

\section{Background}

Extensive traditional livestock husbandry systems often produce high-quality food, create and maintain new species-rich habitats (e.g. hay meadows, wood-pastures), and manage ecosystems for biodiversity conservation [1, 2]. These traditional land-use practices and the related traditional ecological knowledge, are vital for sustainability but they are rapidly disappearing [3]. Knowledge on cattle and sheep grazing is relatively well documented [4, 5] but extensive traditional pig grazing is rarely studied [6].

Keeping pigs in marshes and forests using extensive breeds has been a widespread practice in Europe for millennia [7-9]. Its importance is also indicated by the fact that in the past, forests in Europe were often valued (measured) based on how many pigs they could feed [7, 10-12]. Extensive pig keeping (especially masting) has been well documented since medieval times (e.g. [13, $14])$, and even more so since the nineteenth century [12, 15-22]. Studies on recent extensive pig grazing, however, are scarce $[6,7,23-25]$, and most often document the dehesa system with Iberian pigs kept in wood-pastures and dry grasslands (e.g. [26-28]). There is a huge knowledge gap regarding how free-ranging domestic pigs forage in semi-natural areas (forests, grasslands, marshes) and what ecological knowledge pig keepers possess (need) in such areas.

Today the practice of keeping pigs in closed forests and marshes is almost extinct in Europe, although a revival of the practice is advocated in nature conservation management and organic farming [6, 7, 14, 24, 29-33]. Allowing pigs to range free in semi-natural habitats has positive impacts on the health of the animals and the quality of their meat [34-37] is less resource-intensive (lower time, energy and feed costs; [31]), and is more environmentally friendly $[38,39]$. The practice can even benefit red-listed protected species, e.g. marsh plants and birds $[6,40,41]$.

European forests and wetlands have been radically transformed over the last centuries [42], traditional landuse practices have ceased [22, 33, 43], and multidimensionality of use has decreased $[44,45]$. Prohibition of some traditional uses (e.g. forest grazing, pig grazing) has also contributed to the rapid decline and erosion of related traditional ecological knowledge [43], with severe biodiversity effects [46]. Due to the changing environment and lifestyles, innovations and novel adaptations, based on available knowledge and existing traditions, are needed for the successful continuation of extensive land-use practices (incl. pig keeping) and to further increase their benefits cf. [5, 33].

Ethnobiology-among other things-documents traditional knowledge and practices, the related values and worldviews, and the ways in which traditional knowledge is generated and transmitted [47, 48]. Ethnobotanical knowledge of medicinal and wild food plants is relatively well documented in Europe (e.g. $[49,50])$ but major gaps still exist when it comes to knowledge related to pastoral practices, e.g. about forage plants $[5,51]$. The practices and impacts of traditional livestock grazing on grasslands are also relatively well documented in Europe (e.g. [52-54]). Much less is known about extensive traditional forest and marsh grazing and the foraging behaviour of livestock in these habitats [33, 43, 46, 55], especially about pig grazing $[6,31]$.

Ethnobiologists understand their responsibility to document and archive traditional (folk) knowledge, and to support the continuation of traditional practices and ongoing adaptation and knowledge generation $[3,56,57]$. Documenting traditional knowledge can help knowledge transmission and revival programmes [58-60] and assist in developing culturally appropriate agricultural and conservation regulations and subsidies $[61,62]$.

We are not aware of any recent ethnobiological scientific study on the existing ecological knowledge of traditional pig keepers rearing pigs in semi-natural forests, grasslands and marshes in Europe. All studies are ethnographical or historical, and document historical knowledge and practices. For example, Rodríguez-Estévez et al. [63] list 133 wild and cultivated forage taxa that were traditionally collected and given to dehesa pigs in Spain, while Szabadfalvi [15] reviewed traditional pig keeping in Hungary.

The domestic pig (Sus scrofa domestica L.) belongs to the same species as the wild boar, and there is a rich literature on wild boar foraging on various plant species $[64,65]$. Wild boar can cause serious damage, especially in crop fields, so studies focus more on agricultural areas and crops than on forests and marshes [66-68]. In detailed case studies conducted in semi-natural landscapes, 32-104 wild plant species were found to be foraged by wild boars [64, 69], the closest to our study area [70] but identification of foraged plant species is limited by the methodologies applied (stomach and faeces analysis) [65]. Observation-based studies on behaviour and foraging (including grazing and rooting) of wild boar are scarce [71-73]. Observational studies on free-ranging 
domestic pigs are also rare and done on non-traditionally kept pigs grazing in enclosures $[23,25]$. Our study is the first on traditionally kept, free-ranging pigs foraging in semi-natural habitats.

The main objective of our study was to document the vanishing traditional ecological knowledge and practice of rearing pigs in closed (oak) forests and marshes in a semi-natural floodplain (the Sava-Bosut floodplain in Serbia). This knowledge was once widely possessed and applied across Europe (considering the former extent of the associated practice), but has almost completely disappeared. Now it is possessed only by 100 people at most, almost exclusively over 60 years of age, in some limited locations in Central Europe.

In this paper we studied (1) the traditional ecological knowledge of traditional forest pig keepers (called locally: svinjar) on wild plant species, specifically local folk names, local knowledge of pig-plant relationships (eat, love, avoid, toxic, medicinal etc.), other local uses and salient features of these plant species; and (2) how traditional knowledge of pig foraging behaviour and foraged plants was generated and transmitted in this community.

\section{Methods}

\section{Study area}

Although forest grazing was common even in the second half of the twentieth century in the former Yugoslavia [74], nowadays the floodplains of the Sava, Bosut and Studva rivers are among the very last places where the foraging behaviour of free ranging pigs in closed forests and marshes can be studied in Central Europe [31, 32, 75]. We worked in the territory of the villages Morović and Višnjićevo (marginally in Jamena) close to the administrative borders between the Republic of Serbia, Bosnia \& Herzegovina and the Republic of Croatia (Fig. 1).

The study area belongs to the famous Slavonian oak forest area [76]. The Bosut forest was for centuries part of the border zone between the Austro-Hungarian Monarchy and the Ottoman Empire. The high importance of large-scale pig keeping is documented at least from the seventeenth century [77]. Forest management favouring hardwood species (Quercus, Fraxinus, Ulmus, Carpinus) dates back to the formation of the Military Border [76]. With some technological changes, Quercus robur remained the major tree species [78] and was the cornerstone of pannage. Pig, cattle and sheep grazing was the main use of the forests till the end of the nineteenth century. Forests were managed by irregular selective cutting of valuable timber. With the increased interest of the European timber market in high quality oak timber in the mid of nineteenth century, forest management intensified and the importance of forest grazing decreased [77, 79]. The forests in the study area are now state owned.
The study area is dominated by forests with embedded floodplain marshes, and arable land around villages. The Bosut Forest (21,852 ha) is a local ecological hotspot, recognized as an Important Bird Area (RS007) and a core area of the National Ecological Network. The climate is subcontinental with $11{ }^{\circ} \mathrm{C}$ mean annual temperature and a yearly average precipitation of $700 \mathrm{~mm}$ [80]. The area was cut off from floods in the 1930s and became drier in the twentieth century [31, 32, 81]. Vegetation and flora are diverse $[82,83]$. Forests are dominated by Quercus robur and Carpinus betulus at higher elevations, and Fraxinus angustifolia subsp. pannonica at lower elevations (see auctors of species in Tables 2 and 3, based on [84]). The health status of Quercus robur stands is deteriorating. The herb layer is typical of Central European hardwood forests, but relatively poor in Fagetalia (beech forest) species. Marshes are dominated by Carex riparia, Glyceria maxima, G. fluitans, Iris pseudacorus and Salix cinerea. Grazed marshes are rich in red-listed Nanocyperion (mud preferring) species such as Marsilea quadrifolia and Ludwigia palustris.

Organized pig breeding in the vast lowland forestmarsh complex of the Sava river floodplain was integrated into traditional forest management where the beneficial effects of pig rooting on acorn germination were acknowledged by key forestry experts [85]. The pannage fees and rules were designed to be in line with forest management, with several fee rates depending on the development phase of the foraging pigs and the abundance of mast. According to local svinjars, the now extinct traditional breed Sremska Lasa was longer and larger compared to Mangulica (Mangalitza), and had a black back, white stomach and shorter hair. It farrowed more piglets than Mangulica. Pigs from the 'English Pfeifer' breed were provided to farmers by the state from 1964/1965 to replace the more extensive Sremska Lasa and Mangulica breeds. Mangulica pigs disappeared quickly, but farmers bred Sremska Lasa with Pfeifer and Duroc breeds. Wild boars are present in the area and are hunted. Boars regularly approach pig feeding places and sometimes cross-breed with domestic pigs.

Today, svinjars continue many of the traditional practices but also adapt and innovate them [86]. They keep Yorkshire, Duroc, Landrace and Piétrain breeds, mostly usually their hybrids, which the breeders found to be more resistant and better adapted to year-round outdoor living. The main goal of forest pig keeping is economic (it is cheaper), but the high quality of the meat is also widely valued by svinjars and locals alike (roasted piglets and kulen-a local meaty sausageis more tasty when prepared from forest pigs). The meat is of similar quality to the famous Iberico ham, but is much less well known. Sows are reported to be 


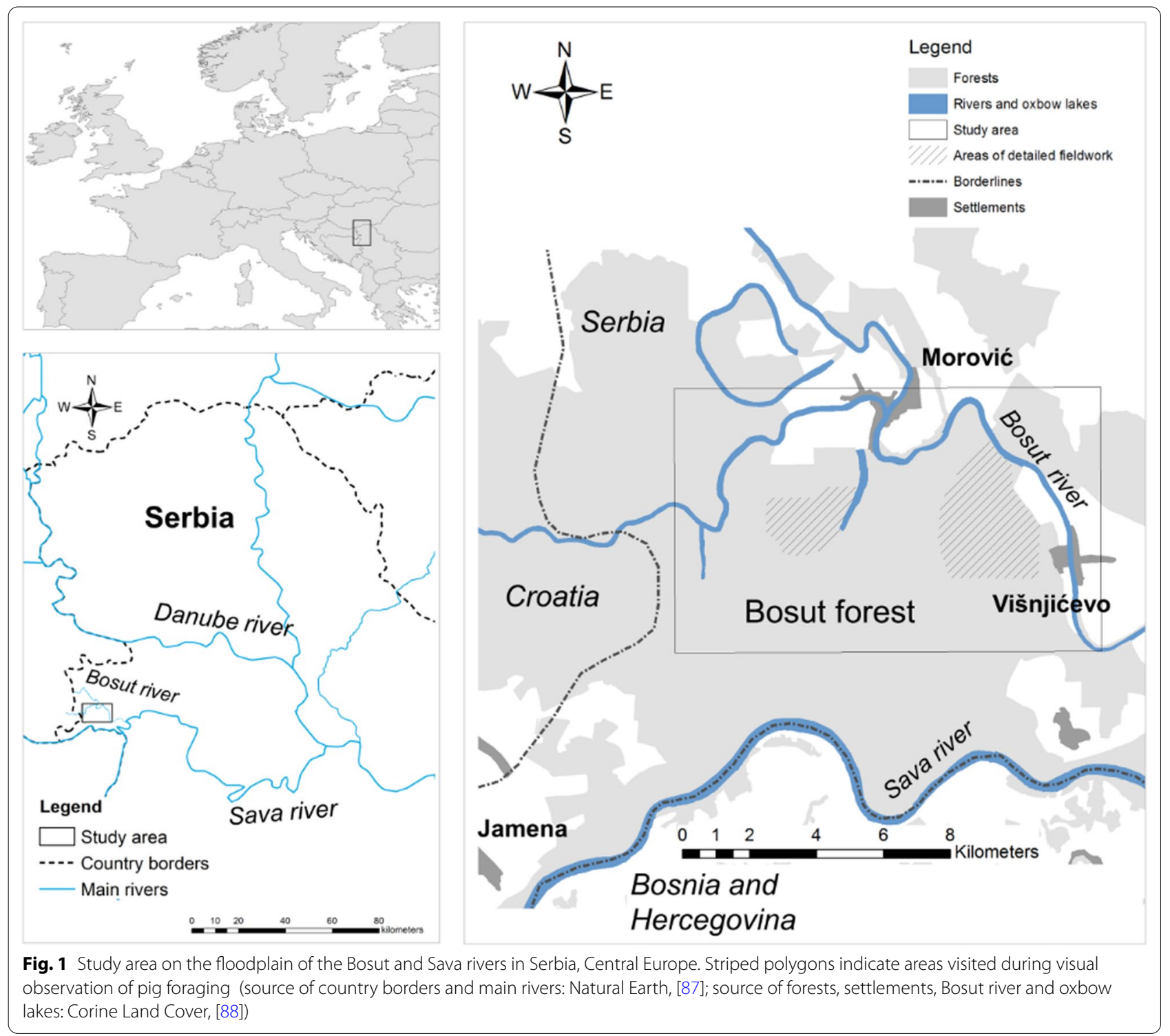

healthier and with a remarkably longer period of fertility in the forest (10-12 years) than if kept at home (5-6 years), and they also live longer. "The forest keeps pigs healthy and cures them." The number of pigs and svinjars and the area used by them are decreasing. Svinjars keep their 50-150 pigs (nowadays fewer) in an area measuring ca. $30-100$ hectares $(<2000$, even $<100$ pigs in total in recent years). Since jackals recolonized the area, most svinjars only keep their $<10-30$ sows in the forest, while piglets are brought to the village after weaning. Pig numbers kept in the forests were much higher until the 1950-1960s, reaching 30-50 thousands (not rarely hundreds per owner). Additionally cattle and sheep were kept in this area earlier in the twentieth century.
Svinjars live in the nearby villages, keep their own pigs, visit them usually every day for several hours, check their health, and provide extra fodder (mostly corn) as needed (e.g. more in drought and in snow). This regular feeding prevents pigs from wandering larger distances. Pigs are kept in the forest all year round, but shoats born in the forest are often kept at home under semi-intensive conditions on intensive fodder (partly because of the risk of predation by the golden jackal). Even modern breeds can become dangerous, protecting their piglets instinctively, so the owners take care to tame them, in some cases treating them almost as pets. The tameness of the pigs also helped our observational research (see below). During the night, pigs and piglets are kept in massive enclosures built from wood. Pigs are under veterinary 
control using modern medicines. African swine fever is encroaching on the region. The forest and marsh 'pastures' and masting are regulated and contracted from the local forestry office (Internal Code of forest farming, PE Vojvodinašume and PE Srbijašume). The forest is fenced towards the agricultural fields to the north and was previously also fenced to the south (towards non-grazed forests). Habitat management by pigs is part of the current and planned future nature conservation management of the local protected area [31,32].

\section{Data collection}

We deliberately used an iterative and flexible methodology, combining and alternating indoor and outdoor interviewing, participatory fieldwork, landscape walks and personal visual observation of pig foraging behaviour, in order to reveal as much of the local knowledge related to pigs and plants as possible. As our plan was to conduct exploratory research into knowledge that has hardly been studied before, no quantification was made at this stage. The seasonality of foraging behaviour and foraging on animal species were not focuses of this paper.

After three preparatory visits to the area in 2014-2016 we interviewed 7 highly knowledgeable svinjars about forest and marsh plant species in April 2017. A larger sample size was not possible because the total number of svinjars is itself small (17 persons). Pictures of 234 locally occurring forest, marsh and other plant species (based on the flora list of the area; [83] printed on A4 size sheets were shown to svinjars (plants were shown in a way traditional knowledge holders tend to recognize them: whole plants or focusing on leaves, fruits, rhizomes; see [89]). We asked about the following topics: (1) the local name of the plant; (2) its relationship with pigs (eat, love, avoid, toxic, medicinal etc.), (3) other uses and salient features of the species. The interviewed svinjars were all above 60 years of age, and had lifelong experience with pig keeping. Interviews lasted $2-4 \mathrm{~h}$, and were conducted mostly at the forest huts, in Serbian, constantly translated to English or Hungarian, and transcribed later in full. Prior informed consent was obtained from all svinjars before the first interviews, adhering to the code of ethics of the International Society of Ethnobiology [57] and the GDPR of the European Union [90].

Prior to the interviews, we surveyed the vegetation of the marshes and forests along a grazing intensity gradient (methods and results in [6] and Demeter et al. ined.) to obtain a detailed understanding of the local flora and vegetation, and to help devise specific questions to ask svinjars about foraged (and non-foraged) species and pig foraging behaviour.
We also conducted participatory fieldwork. We joined svinjars during their grazing trips (8 times) and also went on landscape walks with them (12 times). During these occasions we were able to gather data on plants which were not recognized from pictures (e.g. some grasses and small herbs), and discuss pig behaviour on the spot, and observe and discuss how svinjars generated knowledge about plants and pig behaviour.

We made visual observations of pig foraging behaviour in February, March, April, June, August, October and December 2019, on altogether 21 days. We followed the herd (3-12 pigs) foraging in forests and marshes, and regularly alternated between the closely observed pig(s), every 5-20 min, depending on their movements. We observed ingestive bite selection and avoidance behaviour from morning till mid/late afternoon (see Fig. 2). Most pigs were calm, and the observed individuals were selected at random. We went as close as possible $(0.4-3 \mathrm{~m})$, keeping our impact on the pigs to the minimum while ensuring a good view of the plants near each animal's mouth. When plants were difficult to identify to the species level, we visited the spot just after the animal moved away. We documented how certain plant species were approached or avoided by pigs and how often and for how long certain species were eaten by them. For the less common species our data are not yet representative for a quantitative analysis, so in Table 2 we indicated the depth and reliability of our data with appropriate wording. To avoid differences among observers, most observations were done by the first author who had a full knowledge of the local flora and was experienced in similar studies [5]. Photos and videos were also made to document foraging. The area regularly visited for data collection covers ca. 750 hectares in total (Fig. 1).

During each visit to observe pig foraging we interviewed svinjars about the foraging behaviour of pigs (1) since our last visit and (2) at the moment, as well as (3) the expected foraging behaviour over the next month. We also shared our experiences collected during visual observations and asked svinjars to comment on those. We used two types of elicitation: we asked direct questions (e.g. what do you think, why were some acorns avoided by this pig?) or formulated statements and waited for svinjars' comments (e.g. we observed that pigs graze Ranunculus ficaria only for some seconds). We also made 5 additional detailed interviews about seasonal changes of foraging behaviour (from January till December). We were also keen to learn how pig keeping and pig foraging behaviour have changed since their childhood (1940s-1960s). Some of the most typical and relevant responses (in translation) are indicated in italicized text between quotation marks.

As the main objective of the research was exploratory, investigating and documenting something which was 


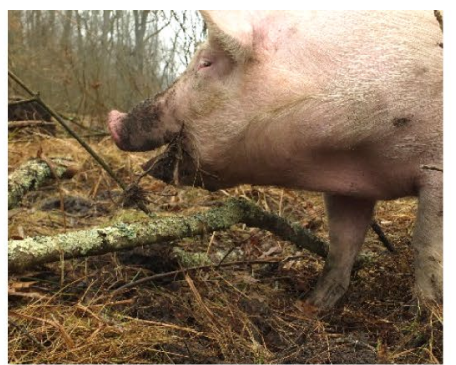

Eating (chewing) Carex sp. 'roots' in marsh in February "for the sweet juice and 'vitamins"

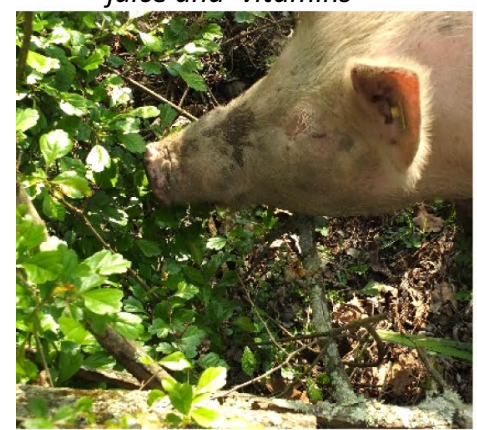

Browsing on fresh Crataegus

laevigata leaves in April "as a salad after their morning corn"

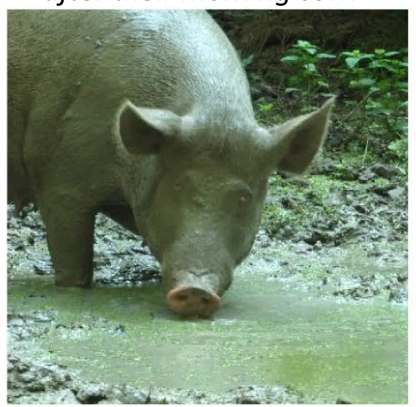

Feeding on Lemna minor and

Spirodela polyrhiza in August, "they like to feed on lokvanj [waterweed]"

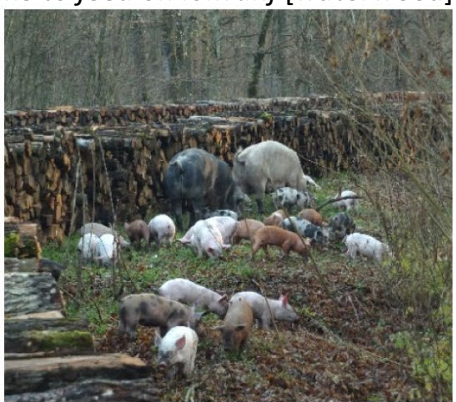

Grazing grasses and herbs on road verges in October,

"it is pitomina [tame]"

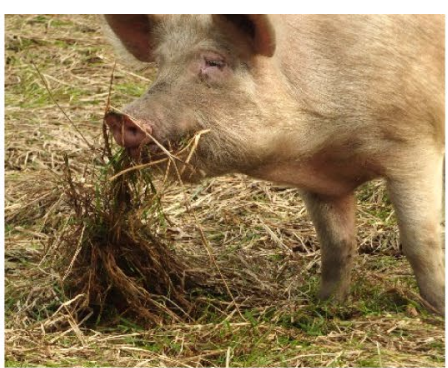

Searching for a little fresh green grass in February, "they need it after eating earthworms for hours"

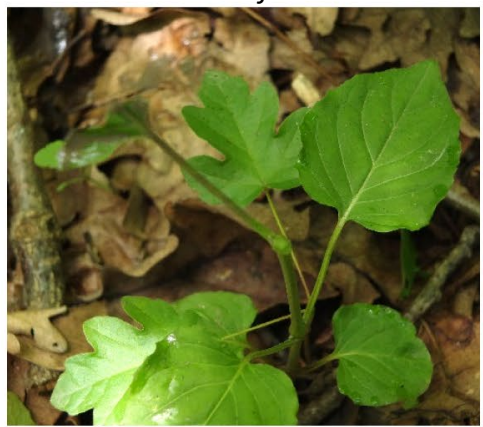

Grazed Circaea lutetiana in June (see

fluid mud on the top left leaf), "we do not notice these small plants"

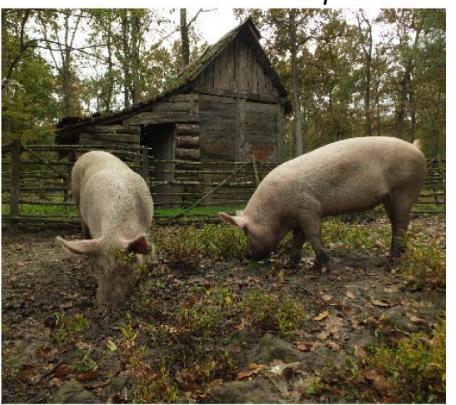

Pigs like foraging on wild forest fruits, here on the seeds of Prunus cerasifera

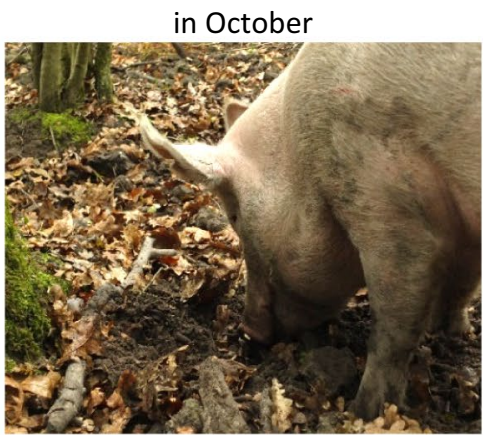

Searching for soft Quercus robur acorns in October, "it is still spicy, but they know which tree has sweeter acorns"

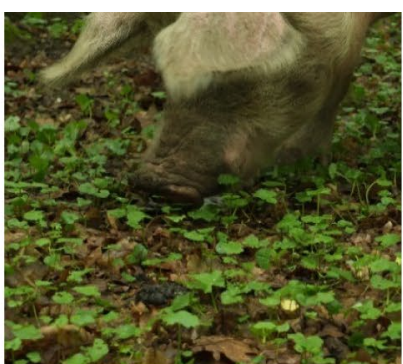

$R$. ficaria is the first green in spring. "They eat it as soon as it is bigger than a fingernail."

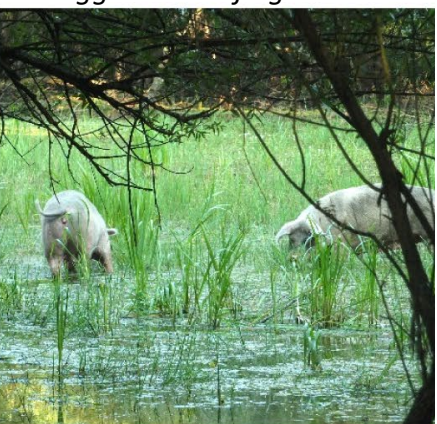

Grazing marsh grasses (Glyceria fluitans, G. maxima) in August, when "the forest is empty/hungry"

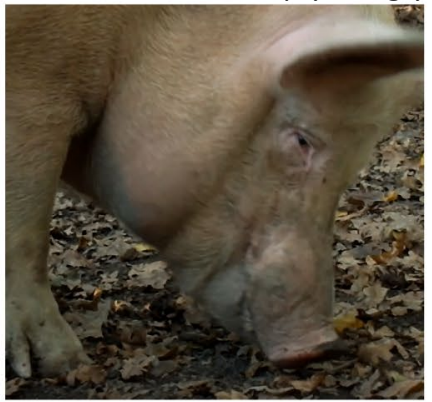

Fallen tree leaves are eaten in summer and autumn

(here: Acer campestre, yellow)

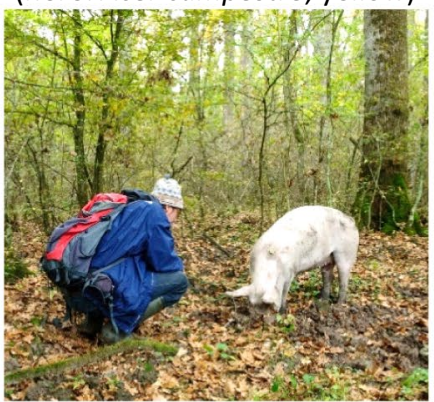

Visual observation of

pig foraging behaviour

(Photo: Ábel Péter Molnár)

Fig. 2 Different types of foraging by free ranging domestic pigs over a year as reported by svinjars and observed by the authors in 2019 in the floodplain forests and marshes of the Bosut and Sava rivers, Serbia (Photos: Zsolt Molnár if not indicated otherwise) (for a video see https://www. youtube.com/watch?v=JJounTmnsXs) 
not considered earlier by ecologists and conservationists, during the whole study we tried to remain as open as possible regarding interview topics and field situations. In some cases our questions might have seemed slightly uncomfortable and unexpected to the svinjars, but they knew that we were keen to understand their knowledge and their culture related to forests, marshes and pigs, so they were very helpful and patient with us. They knew and agreed that the final goal of the research is to publish scientific papers and a book similar to Molnár [89] and Babai et al. [91] on their traditional ecological knowledge and the traditional pig keeping practices and to help the continuation of this still valuable but vanishing land-use practice.

\section{Data analysis}

The 7 main ethnobotanical and 5 season-specific interviews were fully transcribed (520,000 characters). A database was built where data were grouped according to plant species and main topics (foraging behaviour type, season, way of learning about plants, sayings and quotes related to worldview, historical information). All field notes taken during visual observation, participatory fieldwork and landscape walks were also transcribed and inserted into the above database.

We included a plant species in the analysis if at least two independent interview data (i.e. two svinjars) or two independent observations ( 2 days or two herds) were available. Plant names follow the Euro + Med Plant Base [84]. The following species occur in the study area and/ or at least one svinjar had some knowledge about them, but they still lack sufficient ethnobotanical or foraging observational data and were therefore excluded from the present analysis (39 species): Alisma sp., Alopecurus pratensis L., Artemisia annua L., A. vulgaris L., Bromus sterilis L., Calamagrostis epigeios (L.) Roth, Capsella bursa-pastoris (L.) Medik., Cardamine impatiens L., Fallopia convolvulus (L.) Á. Löve, Galium mollugo L., G. palustre L., Geum urbanum L., Gratiola officinalis L., Hyosciamus niger L., Hypochoeris radicata L., Lamium galeobdolon (L.) Crantz, L. album L., Lapsana communis L., Leonurus cardiaca L., Myosotis arvensis (L.) Hill, Noccaea (Thlaspi) perfoliata (L.) Al-Shehbaz, Nostoc sp., Ochlopoa (Poa) annua (L.) H. Scholz, Pastinaca sativa L., Platanthera bifolia (L.) Rich., Potentilla anserina L., Prunella vulgaris L., Ranunculus acris L., Rorippa austriaca (Crantz) Besser, Sanicula europaea L., Sempervivum tectorum L., Sinapis arvensis L., Stachys sylvatica L., Symphyotrichum (Aster) lanceolatum (Willd.) G. L. Nesom, Trifolium patens Schreb., Valerianella sp., Verbena officinalis L., Veronica chamaedrys L. and V. polita Fr.

Local frequency of all studied plant species is provided in Table 2 for a general overview of the local flora.
Frequency data were based on Perić [83] and the extensive fieldwork of the authors. We regarded 'roots' as what svinjars called 'koren' (i.e. roots, bulbs, rhizomes and tubers). We used the following categories of foraging: (1) eaten/loved: whole plants, or at least large parts were eaten (if consumption was often observed, it is indicated in Table 2); (2) nibbled: only smaller parts were eaten; (3) avoided, not eaten: untouched on encounter, occasionally smelled (see [5] for more details). Uncertain but probably relevant data were put into parentheses in order not to lose any already identified information in this exploratory study.

Categories of knowledge depth for the 192 analysed plant species: (1) well known: all or most (5-7) svinjars knew its local folk name(s) and could describe the species in detail; (2) moderately known: only 3-4 svinjars knew the species, and/or knowledge was less detailed; (3) little known: only 1 or 2 svinjars knew the species or if more, knowledge was not detailed (usually rare or small or 'insignificant' species); (4) not known: none of the svinjars knew the species (these species were only included in Table 2 if visual foraging observation data by the authors was available). The level of local knowledge of each species was compared to the regional level knowledge of the species (from well known to not known in other areas of the Carpathian Basin) using Molnár [89], Dénes et al. [92], Babai et al. [91], and Molnár [93].

\section{Results}

\section{Svinjars' knowledge of plants and observations on pig foraging behaviour}

We collected ethnobotanical and/or visual observation data for 237 species, of which 192 could be analysed (i.e. had two independent data). Svinjars knew 181 of the 192 species. 102 plant species were well known by them (Table 1), 27 species were moderately known, 52 little known, and 11 species that occurred in the forests and marshes were probably not known by them (Tables 2 and 3 ). There were 10 species that were well or moderately known but not named by svinjars. Svinjars regretted that they could not remember any name.

Ninety-eight species were reported by svinjars as eaten by pigs and 56 as not eaten. There were 38 species (of the 192) for which svinjars could not give information about pig foraging (how much pigs like the species). 28 species were observed by the authors as eaten regularly and 21 as nibbled by pigs, while 17 species were seen as deliberately avoided. Overlaps between svinjars' and authors' observations were moderate. For 126 plant species authors were not able to observe any foraging or avoidance behaviour because of the lack of observed encounters with the species by pigs in the field (of the 126 species 41 species did not occur in the observation area). Leaves of 
Table 1 Overview of the number of plant taxa: svinjars' plant knowledge and authors' observations, species that were known by svinjars as eaten or avoided by pigs and/or observed as eaten or avoided by pigs

\begin{tabular}{|c|c|c|c|}
\hline \multirow[t]{2}{*}{ Categories of knowledge depth } & \multicolumn{3}{|c|}{ Number of plant taxa (from the analysed 192) } \\
\hline & Trees and shrubs & Grasses, sedges and rushes & $\begin{array}{l}\text { Others } \\
\text { (herbs } \\
\text { etc.) }\end{array}$ \\
\hline Well known & 28 & 12 & 62 \\
\hline Moderately known & 3 & 3 & 21 \\
\hline Little known & 6 & 5 & 41 \\
\hline Not known & 0 & 1 & 10 \\
\hline Total & 37 & 21 & 134 \\
\hline Pig foraging behaviour & Svinjars' knowledge & Authors' observations & Overlaps \\
\hline Regularly eaten, loved & 61 & 28 & 21 \\
\hline Nibbled, rarely eaten & 37 & 21 & 10 \\
\hline Not eaten & 56 & 17 & 8 \\
\hline $\begin{array}{l}\text { No knowledge by svinjars / No observation by the } \\
\text { authors }\end{array}$ & 38 & 126 & 10 \\
\hline Total & 192 & 192 & 49 \\
\hline
\end{tabular}

92 species, fruits or seeds of 21 species and 'roots' of 20 species were reported or observed as eaten.

Species that were common or moderately common in the forest but were only little known by svinjars were Circaea lutetiana, Moehringia trinervia, Veronica montana and $V$. hederifolia, Lysimachia nummularia, Glechoma hederacea, Brachypodium sylvaticum, Callitriche sp., Carpesium spp. and Genista tinctoria. Some species were rare in the forest but were known by svinjars from gardens (Cornus mas, Galanthus nivalis, Convallaria majalis) and svinjars knew a lot about two, regionally widely known species (Fagus sylvatica and Allium ursinum) not found recently in the area. Many other of the well known species were rare in the forest but common in the arable landscapes around the villages (e.g. Cynodon dactylon, Sonchus spp.). Svinjars knew many of the invasive alien species well.

For some 'insignificant for svinjars' species, svinjars did not know whether pigs eat them or not, though three were regularly observed by the authors as eaten (Circaea lutetiana, Rorippa amphibia, Leersia oryzoides), while others were not eaten based on our observations (Lycopus spp., Carpesium spp.). Some species were less well known by svinjars than in other parts of the Carpathian Basin (Hypericum sp., Colchicum autumnale, Achillea sp., Chelidonium majus, Lotus corniculatus), while Acer tataricum, Persicaria dubia and the 'small forest-Carex' folk taxon that includes Carex remota, C. sylvatica and $C$. divulsa were better known.

The most common plant forages of pigs (mentioned or observed) were fruits of trees (esp. Quercus and fleshy forest fruits), marsh grasses (esp. Agrostis and Glyceria), forest herbs (esp. Ranunculus ficaria and Circaea lutetiana), marsh plants with nutritious 'roots' (esp. Carex spp. and Iris pseudacorus), shrubs and young trees with young fresh leaves (esp. Crataegus and Carpinus), as well as 'tame' plants that grow in the sun ("pitomina", e.g. Persicaria dubia and Erigeron annuus). Some species were reported as especially loved by pigs (even if some were less available to them): Quercus robur acorns (it is the primary forage, always eaten if available), Polygonum aviculare, Amaranthus retroflexus and Sonchus spp. leaves, and Pyrus sp., Juglans regia, Prunus cerasifera and Trapa natans fruits. Svinjars spoke enthusiastically about how eagerly pigs forage on these species.

Some species (e.g. Salix alba, Ulmus minor) were not eaten or only rarely because in April-June many other"sweeter"-species were available ("nothing forces pigs to eat them, pigs are choosy in these months"). Svinjars reported that pigs graze more grass in wet years, and even eat grass from below the water. Many of the invasive alien species were not eaten by pigs, e.g. Ambrosia artemisiifolia, Amorpha fruticosa, Asclepias syriaca, Phytolacca americana, Robinia pseudoacacia, Solidago gigantea, Sorghum halepense, Vitis sp., while Erigeron annuus (little known by svinjars) was regularly eaten.

Svinjars argued that traditional pig breeds (e.g. the black coloured Sremska Lasa breed) were less selective when grazing and more 'knowledgeable' about edible forest and marsh plants, as they received less additional fodder (corn). 
Table 2 Svinjars' knowledge of wild plant species and visual observations by the authors of pig foraging of the studied plant species in the Sava-Bosut floodplain, Serbia

\begin{tabular}{|c|c|c|c|}
\hline $\begin{array}{l}\text { Latin name, (local frequency), } \\
\text { depth of local knowledge, folk } \\
\text { names, (depth of knowledge } \\
\text { regionally-Carpathian Basin) }\end{array}$ & $\begin{array}{l}\text { Pigs eat/don't eat (svinjars' } \\
\text { reports) }\end{array}$ & $\begin{array}{l}\text { Pigs eat/don't eat (authors' } \\
\text { observations) }\end{array}$ & $\begin{array}{l}\text { Other uses and salient features } \\
\text { (e.g. impact on pigs) reported by } \\
\text { svinjars }\end{array}$ \\
\hline
\end{tabular}

\section{Trees}

Acer campestre L. (3), well known, klen (well known)

Acertataricum L. (2), well known, žesta (fierce, spicy) (moderately known)

Carpinus betulus L. (4), well known, grab (well known)

Prunus avium (L.) L. (1), well known, trešnja (cherry) (well known)

Fagus sylvatica L. (0), well known, bukva (well known)

Fraxinus angustifolia Vahl (3), well known, jasen (well known)

Fraxinus pennsylvanica Marshall (2), little known, Amerikanac/divlji jasen (American/wild ash) (little known)

Juglans nigra L. (1), moderately known, divlji orah (wild walnut) (moderately known)

Juglans regia L. (1), well known, nežni orah (tender walnut) (well known)

Malus sylvestris (L.) Mill. (2), well known, divlja jabuka (wild apple) (well known)

Morus alba L. (2), well known, dud, fruits: dudinje (well known)

Populus alba L., P. nigra L., P. $\times$ canadensis Moench, $P$. tremula L. (2), well known, bela topola (white poplar), crna topola (black poplar), Kanadska topola (Canadian or hybrid poplar), jašika/jošika (aspen) (well known)
Leaves are eaten eagerly in spring, liked more than Carpinus leaves, eaten less in summer but longer than other tree leaves, also fallen leaves in autumn, fruits are eaten in need

Neither leaves nor fruits are eaten

(It was nibbled)

Leaves are liked and eaten, but much less in summer, also buds and young twigs, seeds and germinating and soaked seeds are eaten eagerly for whole days from late autumn till spring if there is no acorn

Fruits are eaten (domestic cherry)

In the past, the black pigs were N.O driven for masting to neighbouring mountains

Leaves on trees are not eaten, fallen Leaves on trees were not eaten twigs and leaves are eaten, fruits are (sometimes nibbled), fallen leaves not eaten were eaten

N.d

Nuts are eaten

N.O

Leaves, young twigs and seeds were eaten

N.O

N.O

Nuts are eaten, leaves are not eaten N.O

Fruits are eaten but less and starting later than Pyrus fruits, more till acorns fall or when there is no acorn (the forest is empty), leaves are nibbled

Fruits are eaten, leaves are nibbled, N.o fallen leaves are eaten

It is not eaten, rarely the young N.O

eaves were eaten, also fallen leaves

Leaves have a sweet taste

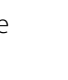


Table 2 (continued)

\begin{tabular}{|c|c|c|c|}
\hline $\begin{array}{l}\text { Latin name, (local frequency), } \\
\text { depth of local knowledge, folk } \\
\text { names, (depth of knowledge } \\
\text { regionally-Carpathian Basin) }\end{array}$ & $\begin{array}{l}\text { Pigs eat/don't eat (svinjars' } \\
\text { reports) }\end{array}$ & $\begin{array}{l}\text { Pigs eat/don't eat (authors' } \\
\text { observations) }\end{array}$ & $\begin{array}{l}\text { Other uses and salient features } \\
\text { (e.g. impact on pigs) reported by } \\
\text { svinjars }\end{array}$ \\
\hline $\begin{array}{l}\text { Prunus cerasifera Ehrh. (2), well } \\
\text { known, džanarika, zerželija, divlja } \\
\text { šljiva (wild plum) (well known) }\end{array}$ & $\begin{array}{l}\text { Fruits, later seeds and less the } \\
\text { leaves are eaten }\end{array}$ & Seeds were eaten & $\begin{array}{l}\text { Used for rakija (brandy), jam, eaten } \\
\text { fresh by people }\end{array}$ \\
\hline $\begin{array}{l}\text { Pyrus spp. (wild and ancient semi- } \\
\text { wild) (2), well known, divlja kruška } \\
\text { (wild pear) (well known) }\end{array}$ & $\begin{array}{l}\text { Fruits are eaten eagerly from late } \\
\text { August till acorns fall, and eaten } \\
\text { up entirely if there is no acorn (till } \\
\text { spring), but not if'not needed', } \\
\text { preferred to wild apple, pigs wait } \\
2-3 \text { days for after-ripening of fallen } \\
\text { fruits, some trees are only eaten } \\
\text { later, leaves are eaten (by male pigs) }\end{array}$ & $\begin{array}{l}\text { N.o. (the fruit of a "bad" tree was } \\
\text { not eaten) }\end{array}$ & $\begin{array}{l}\text { Grows in open forests and around } \\
\text { marshes, trees with bad tasting } \\
\text { fruits are avoided, eaten by people, } \\
\text { used for rakija (brandy), turšija } \\
\text { (pickles) and jam, also vinegar, } \\
\text { healthy, there are ancient (grafted), } \\
\text { not real wild pear varieties, these } \\
\text { are ancient types of domesticated } \\
\text { pears, not wild, sweet as honey }\end{array}$ \\
\hline $\begin{array}{l}\text { Quercus cerris L. (1), well known, cer } \\
\text { (well known) }\end{array}$ & $\begin{array}{l}\text { Acorns are eaten, but only in } \\
\text { spring after they are wettened and } \\
\text { softened and not if } Q \text {. robur acorn is } \\
\text { available, leaves are rarely eaten }\end{array}$ & N.o & $\begin{array}{l}\text { Rare here, very spicy, worth half } \\
\text { compared to } Q \text {. robur acorns, may } \\
\text { cause miscarriage in pigs, pigs were } \\
\text { driven to its acorns if } Q \text {. robur acorn } \\
\text { was not available, wild boars also } \\
\text { prefer } Q \text {. robur acorns, acorns burn } \\
\text { well in the stove or furnace, wood is } \\
\text { less valuable than of } Q \text {. robur }\end{array}$ \\
\hline $\begin{array}{l}\text { Quercus robur L. (5), well known, } \\
\text { hrast, lužnjak, acorn: žir (well } \\
\text { known) }\end{array}$ & $\begin{array}{l}\text { Acorns are very much liked, the pri- } \\
\text { mary food of pigs, unripe, recently } \\
\text { ripened and dry acorns are eaten } \\
\text { less, are very spicy, liked if soaked } \\
\text { by rains by November, pigs know } \\
\text { where to find the trees fruiting the } \\
\text { sweetest acorns, pigs search for } \\
\text { acorns in wood mice' stores under } \\
\text { stumps (nado= the store), acorns } \\
\text { fallen into marshes are kept fresh } \\
\text { and eaten months later, cotyledons } \\
\text { of germinated and thus very sweet } \\
\text { acorns are uprooted, leaves are } \\
\text { eaten, but only when young, and } \\
\text { only the freshest leaves from twigs } \\
\text { fallen in summer, otherwise too } \\
\text { bitter, home-kept pigs eat even dry } \\
\text { leaves (of badnjak) }\end{array}$ & $\begin{array}{l}\text { Acorns were eaten if available, } \\
\text { germinating acorns were preferred, } \\
\text { leaves were not eaten, only young } \\
\text { leaves }\end{array}$ & $\begin{array}{l}\text { There are early and late trees, acorn } \\
\text { production is forecasted by svinjars } \\
\text { from late spring onwards, frost kills } \\
\text { flowers, till the day of the Apostles } \\
\text { Peter and Paul (12th July in the } \\
\text { Orthodox calendar) acorns only } \\
\text { grow on Saturdays, later every day, } \\
\text { Saint Elijah (hot days in July) kills } \\
\text { acorns, acorn is as good for pigs as } \\
\text { kulen (very meaty sausage) is for } \\
\text { us, but pigs need enough water, } \\
\text { fatten less on spicy acorns, acorns } \\
\text { get sweeter and softer after rains, } \\
\text { acorns used to be shaken off from } \\
\text { early ripening trees in August, } \\
\text { collected in October, kept in stacks } \\
\text { and given to home-kept or to forest } \\
\text { pigs, trees are less productive and } \\
\text { healthy nowadays, acorn is col- } \\
\text { lected for forestry. The bacon fat is } \\
\text { getting yellowish and firm from the } \\
\text { acorn pannage }\end{array}$ \\
\hline $\begin{array}{l}\text { Robinia pseudoacacia L. (2), well } \\
\text { known, bagrem (well known) }\end{array}$ & $\begin{array}{l}\text { Leaves even if fallen are not eaten, } \\
\text { nor flowers or pods }\end{array}$ & N.o & $\begin{array}{l}\text { Not a common tree here, medicinal } \\
\text { tea, we ate the flowers, honey } \\
\text { plant, sheep eat leaves and pods, } \\
\text { has good timber }\end{array}$ \\
\hline $\begin{array}{l}\text { Salix euxina I. V. Belyaeva ["fragilis"] (3), } \\
\text { well known, vrba, bela (white) vrba } \\
\text { (well known) }\end{array}$ & Young and fallen leaves are eaten & N.o & $\begin{array}{l}\text { Twigs break easily, used for whistles } \\
\text { [in spring] }\end{array}$ \\
\hline $\begin{array}{l}\text { Tilia tomentosa Moench, T. platy- } \\
\text { phyllos Scop. }(1+1) \text {, moderately } \\
\text { known, lipa (well known) }\end{array}$ & It is not eaten & N.o & $\begin{array}{l}\text { In the village, honey plant, the } \\
\text { wild variant blooms later and has } \\
\text { smaller leaves }\end{array}$ \\
\hline $\begin{array}{l}\text { Ulmus laevis Pallas (2), well known, } \\
\text { vez (ties, bond) (well known) }\end{array}$ & $\begin{array}{l}\text { Leaves are not eaten, seeds are } \\
\text { eaten a bit }\end{array}$ & N.o & Not very useful, not planted \\
\hline
\end{tabular}


Table 2 (continued)

\begin{tabular}{llll}
\hline $\begin{array}{l}\text { Latin name, (local frequency), } \\
\text { depth of local knowledge, folk } \\
\text { names, (depth of knowledge } \\
\text { regionally-Carpathian Basin) }\end{array}$ & $\begin{array}{l}\text { Pigs eat/don't eat (svinjars' } \\
\text { reports) }\end{array}$ & $\begin{array}{l}\text { Pigs eat/don't eat (authors' } \\
\text { observations) }\end{array}$ & $\begin{array}{l}\text { Other uses and salient features } \\
\text { (e.g. impact on pigs) reported by } \\
\text { svinjars }\end{array}$ \\
\hline $\begin{array}{l}\text { Ulmus minor Mill. (2), well known, } \\
\text { brest (well known) }\end{array}$ & $\begin{array}{l}\text { Young leaves and fallen seeds are } \\
\text { eaten but not eagerly }\end{array}$ & $\begin{array}{l}\text { Leaves were eaten once } \\
\text { (n) }\end{array}$ & $\begin{array}{l}\text { Not very useful, a good mushroom } \\
\text { grows on it (Pleurotus ostreatus), } \\
\text { farmers used to cut and leave a log } \\
\text { for the mushroom to develop }\end{array}$
\end{tabular}

\section{Shrubs}

Amorpha fruticosa L. (3), well known, Leaves are not eaten, nibbled when N.o divlji bagremac (wild Robinia), fašina young (bundle of loppings) (well known)

\section{Cornus mas L. (1), well known, dren} (well known)

Fruits are eaten

N.o

Cornus sanguinea L. (3), well known, sibovina, svibovina, svib (related to May) (well known)
It is not eaten, leaves are nibbled when young, fruits eaten in need

Fallen fruits are eaten, leaves are not eaten

Leaves are eaten when fresh and spikes are soft, a good 'salad' after morning corn for pigs, fallen fruits are eaten especially in snowy winter distinguished (the two species), fruit: gloginje (well known)

Euonymus europaeus L. (2), little known, uncertain names only (moderately known)

Prunus spinosa L. (2), well known, trnjina (thorny) (well known)

Rosa canina L. (2), well known, divlja ruža (wild rose), fruit: šipurak, šipkovina (well known)

(It is not eaten)

Leaves are not eaten, fallen fruits are eaten in autumn and winter

Leaves are not eaten, too spiky, fruits are rarely eaten, in winter when the forest is 'empty'

Rubus caesius L., R. hirtus aggr. $(3+2)$, Leaves are eaten especially in well known, jagode (strawberry), pepeljuga (Cinderella), kupina, ostruga (scrape off) (well known)

Ruscus aculeatus L. (1), moderately known, divlji šimšir (wild boxwood) (moderately known)

\section{winter, and rarely the fruits}

It is not eaten

N.O
N.o

N.o

Leaves were regularly and patiently (1-3 min) eaten in spring and summer, pulled down from twigs, n.o. for fruits
"Poisons" (i.e. overgrows) marshes, pigs avoid such places, cattle, sheep and red deer eat, bees like it, used for baskets

There isn't much here, medicinal, blooms early but fruits late, fruits used for jam and put into rakija (brandy), making strengthening medicine, wood good as herder sticks and tomato stakes

Wood is flexible, good for fences, long-lasting in wattle-and-daub walls, baskets, brooms, but not as herder sticks because it causes goitre to pigs, white-flowers, fruits paint your skin blue but cause itching

People also eat fruits

Likes open forests and open places, thorns disturb pigs, flowers are medicinal, C. laevigata: has looser crown structure, blooms earlier, and grows in forest interiors, it was thrown onto water and fish were caught in the shade, good for herder sticks, a plant of the devil

Rare, grows one by one
Leaves were rarely nibbled

N.o

Leaves were eaten, also in summer
Good for rakija (brandy), berries are also eaten by people after the first frost, used for refreshing tea

Along roads, canals, in forest edges, not in the forest, prickles disturb pigs, used for jam, tea, put into rakija (brandy), healthy, petals soaked in water

Leaves stay green in winter, grows along roads and forest edges, spreads as livestock numbers decrease, the wild type is more tasty, good for jam, roe deer love it

Rare here, green in winter, red deer doesn't eat it either, ornamental, collected, used to keep away mice from drying meat hung on rods and to block mouse holes 
Table 2 (continued)

\begin{tabular}{|c|c|c|c|}
\hline $\begin{array}{l}\text { Latin name, (local frequency), } \\
\text { depth of local knowledge, folk } \\
\text { names, (depth of knowledge } \\
\text { regionally-Carpathian Basin) }\end{array}$ & $\begin{array}{l}\text { Pigs eat/don't eat (svinjars' } \\
\text { reports) }\end{array}$ & $\begin{array}{l}\text { Pigs eat/don't eat (authors' } \\
\text { observations) }\end{array}$ & $\begin{array}{l}\text { Other uses and salient features } \\
\text { (e.g. impact on pigs) reported by } \\
\text { svinjars }\end{array}$ \\
\hline $\begin{array}{l}\text { Salix cinerea L. (3), well known, } \\
\text { ivovina, ivovina vrba, a kind of vrba } \\
\text { (willow) (well known) }\end{array}$ & It is not eaten, neither the roots & N.o & $\begin{array}{l}\text { In marshes, medicinal, deer eat it } \\
\text { and clean their antlers on its twigs } \\
\text { (thus may kill bushes), if catkins are } \\
\text { taken into the house, hens stop } \\
\text { laying eggs, used for baskets and } \\
\text { whistles }\end{array}$ \\
\hline $\begin{array}{l}\text { Sambucus nigra L. (2), well known, } \\
\text { zova (well known) }\end{array}$ & $\begin{array}{l}\text { It is not eaten, neither leaves nor } \\
\text { fruits (seeds/fruits are eaten rarely) }\end{array}$ & N.o & $\begin{array}{l}\text { For pigs the only use is that they } \\
\text { like its shade..., medicinal, used } \\
\text { for syrup, rakija (brandy) and jam, } \\
\text { red deer, cattle and sheep eat it, a } \\
\text { mushroom good for "elderly men's } \\
\text { problem" grows on it }\end{array}$ \\
\hline $\begin{array}{l}\text { Viburnum opulus L. (2), little known, } \\
\text { kereće grožđe (dog grape) (little } \\
\text { known) }\end{array}$ & It is not eaten & N.o & Has red berries \\
\hline $\begin{array}{l}\text { Vitis sp. (non-native) (1), moderately } \\
\text { known, divlja loza (wild vine) (well } \\
\text { known) }\end{array}$ & $\begin{array}{l}\text { It is not eaten, neither leaves nor } \\
\text { fruits }\end{array}$ & N.o & Grows around marshes \\
\hline \multicolumn{4}{|l|}{ Forest herbs } \\
\hline $\begin{array}{l}\text { Ajuga reptans L. (4), well known, ran- } \\
\text { jenika/ranjena/ ranjenik trava (grass } \\
\text { of the wounded) (n.d.) }\end{array}$ & It is not eaten, nibbled when young & $\begin{array}{l}\text { It was not eaten, but nibbled in } \\
\text { winter }\end{array}$ & $\begin{array}{l}\text { In forests, medicinal for wounds, } \\
\text { calluses, pus, pimples and stomach, } \\
\text { it stays green for the winter so } \\
\text { that(!) people in need can find it } \\
\text { under the snow }\end{array}$ \\
\hline $\begin{array}{l}\text { Allium ursinum L. (0), well known, } \\
\text { sremuš (belongs to the Srem } \\
\text { region) (well known) }\end{array}$ & N.d & N.o & $\begin{array}{l}\text { Doesn't grow here, only in the } \\
\text { mountains, edible and healthy, } \\
\text { people collect the leaves }\end{array}$ \\
\hline $\begin{array}{l}\text { Athyrium filix-femina (L.) Roth, Dryop- } \\
\text { teris filix-mas (L.) Schott }(2+2) \text {, well } \\
\text { known, paprat (well known) }\end{array}$ & It is not eaten, not even the roots & It was not eaten & $\begin{array}{l}\text { In wet parts of the forest, in wells, } \\
\text { green for the whole year, pretty, } \\
\text { collected for bouquets, I have } \\
\text { watched it for long - it has no } \\
\text { flower! }\end{array}$ \\
\hline $\begin{array}{l}\text { Carpesium abrotanoides } L ., C \text {. cernuum } \\
\text { L. }(2+1) \text {, little known (n.d.) }\end{array}$ & N.d & It was not eaten (but smelled) & \\
\hline $\begin{array}{l}\text { Circaea lutetiana L. (3), little known } \\
\text { (n.d.) }\end{array}$ & N.d & $\begin{array}{l}\text { It was regularly eaten, for seconds, } \\
\text { max. } 2 \text { min }\end{array}$ & Too small for us to notice... \\
\hline $\begin{array}{l}\text { Clematis vitalba L. (1), moderately } \\
\text { known, divlja loza (wild vine), } \\
\text { mistaken for Humulus (n.d.) }\end{array}$ & N.d & N.o & We played Tarzan... \\
\hline $\begin{array}{l}\text { Convallaria majalis L. (1), well known, } \\
\text { đurđevak (George flower, blooming } \\
\text { around Orthodox St. George's day), } \\
\text { zvončići (small bells) (well known) }\end{array}$ & It is not eaten & N.o & $\begin{array}{l}\text { Grows in patches, collected by } \\
\text { people, fragrant, medicinal }\end{array}$ \\
\hline $\begin{array}{l}\text { Ficaria verna Huds. (4), well known, } \\
\text { pšenac (tubers are similar to wheat } \\
\text { grains: pšenica), rarely: kopitnjak } \\
\text { (horse shoe) (well known) }\end{array}$ & $\begin{array}{l}\text { It is eaten as soon as it is big- } \\
\text { ger than a fingernail, less eaten } \\
\text { if in bloom (bitter), flowers are } \\
\text { not eaten, available till 10th May, } \\
\text { bulbs are eaten in autumn but not } \\
\text { eagerly }\end{array}$ & $\begin{array}{l}\text { Leaves were eaten regularly and } \\
\text { often patiently for } 0.5-3 \mathrm{~min}\end{array}$ & $\begin{array}{l}\text { Grows in early spring, this is the first } \\
\text { fresh green in the forest, has a bitter } \\
\text { taste, has small bulbs like a wheat } \\
\text { grain but they only make the pigs' } \\
\text { hair grow (not the meat) }\end{array}$ \\
\hline $\begin{array}{l}\text { Galanthus nivalis L. (1), well known, } \\
\text { visibaba (hanging grandma) (well } \\
\text { known) }\end{array}$ & It is not eaten & N.o & $\begin{array}{l}\text { Rare here, blooms at around snow- } \\
\text { melt, makes you happy, disappears } \\
\text { by summer, flowers are picked, } \\
\text { otherwise not useful }\end{array}$ \\
\hline
\end{tabular}


Table 2 (continued)

\begin{tabular}{|c|c|c|c|}
\hline $\begin{array}{l}\text { Latin name, (local frequency), } \\
\text { depth of local knowledge, folk } \\
\text { names, (depth of knowledge } \\
\text { regionally-Carpathian Basin) }\end{array}$ & $\begin{array}{l}\text { Pigs eat/don't eat (svinjars' } \\
\text { reports) }\end{array}$ & $\begin{array}{l}\text { Pigs eat/don't eat (authors' } \\
\text { observations) }\end{array}$ & $\begin{array}{l}\text { Other uses and salient features } \\
\text { (e.g. impact on pigs) reported by } \\
\text { svinjars }\end{array}$ \\
\hline $\begin{array}{l}\text { Hedera helix L. (3), well known, bršljen, } \\
\text { bršljan (browsed), a kind of puza- } \\
\text { vica (creeper) (well known) }\end{array}$ & $\begin{array}{l}\text { It is eaten especially in winter, fruits } \\
\text { are not eaten }\end{array}$ & It was not eaten & $\begin{array}{l}\text { Climbs on trees, "poisonous" for } \\
\text { trees, blooms in late autumn, you } \\
\text { can easily stumble on it, red and } \\
\text { roe deer, cattle, goat and sheep } \\
\text { also eat it, bees visit flowers }\end{array}$ \\
\hline $\begin{array}{l}\text { Leucojum aestivum L. (2), moderately } \\
\text { known, barska visibaba (marsh } \\
\text { Galanthus), letnja visibaba (summer } \\
\text { Galanthus), zvončić (bells) (moder- } \\
\text { ately known) }\end{array}$ & $\begin{array}{l}\text { Neither leaves nor flowers are } \\
\text { eaten, only the roots, and pigs like } \\
\text { rooting around it }\end{array}$ & It was not eaten & $\begin{array}{l}\text { In flooded places, has larger flowers } \\
\text { than Galanthus, slightly fragrant } \\
\text { (picking by people was not men- } \\
\text { tioned) }\end{array}$ \\
\hline $\begin{array}{l}\text { Moehringia trinervia (L.) Clairv. (3), } \\
\text { little known, mišovina, mišovkinja } \\
\text { (part of the Stellaria media folk } \\
\text { taxon) (n.d.) }\end{array}$ & It is eaten & It was eaten once & $\begin{array}{l}\text { Grows both in forests and fields (cf. } \\
\text { Moehringia and Stellaria), has small } \\
\text { white flowers }\end{array}$ \\
\hline $\begin{array}{l}\text { Neottia nidus-avis (L.) Rich. (2), little } \\
\text { known, name not remembered } \\
\text { (n.d.) }\end{array}$ & It is not eaten & N.o & $\begin{array}{l}\text { It looks as if it has dried out (always } \\
\text { brown), has a thick and hollow root }\end{array}$ \\
\hline $\begin{array}{l}\text { Potentilla indica (Jacks.) Th. Wolf (1), } \\
\text { little known, rarely: divlja jagoda } \\
\text { (wild strawberry), (n.d.) }\end{array}$ & It is not eaten & N.o & A newcomer, game eats it \\
\hline $\begin{array}{l}\text { Primula acaulis (L.) L. (3), well known, } \\
\text { jagorčevina (well known) }\end{array}$ & $\begin{array}{l}\text { Leaves are eaten when young / are } \\
\text { not eaten }\end{array}$ & N.o & $\begin{array}{l}\text { Grows in early spring, medicinal, } \\
\text { flowers are used in rakija (brandy) }\end{array}$ \\
\hline $\begin{array}{l}\text { Rumex sanguineus L. (3), moderately } \\
\text { known, kind of zelje, štavalj (mate- } \\
\text { rial for tanning, ancient meaning } \\
\text { is sour, tart), masnih (greasy on } \\
\text { touch) (little known) }\end{array}$ & It is eaten & It was eaten once & Sour \\
\hline $\begin{array}{l}\text { Scilla bifolia L. (3), well known, } \\
\text { procepak, pricepak, precepak (split), } \\
\text { divlji zumbul ("wild hyacinth") } \\
\text { (moderately-well known) }\end{array}$ & It is never eaten & N.o & $\begin{array}{l}\text { Blooms in early spring in the forest, } \\
\text { after Galanthus and before Viola }\end{array}$ \\
\hline $\begin{array}{l}\text { Scrophularia nodosa L. (2), little } \\
\text { known (little known) }\end{array}$ & It is not eaten & It was not eaten & \\
\hline $\begin{array}{l}\text { Veronica montana L. (3), little known } \\
\text { (n.d.) }\end{array}$ & (It is not eaten) & It was eaten once, was also avoided & \\
\hline $\begin{array}{l}\text { Viola alba Besser (2), well known, } \\
\text { bela (white) ljubičica (from 'lju- } \\
\text { bica'= loved /dear woman) (well } \\
\text { known) }\end{array}$ & (It is eaten) (It is not eaten) & N.o & \\
\hline $\begin{array}{l}\text { Viola reichenbachiana Boreau (3), well } \\
\text { known, plava (blue) ljubičica (well } \\
\text { known) }\end{array}$ & (It is not eaten) (It is eaten) & $\begin{array}{l}\text { It was eaten (in August regularly), } \\
\text { sometimes avoided }\end{array}$ & Pigs wish for this green \\
\hline \multicolumn{4}{|l|}{ Wetland plants, waterweeds } \\
\hline $\begin{array}{l}\text { Butomus umbellatus L. (2), moderately } \\
\text { known, koštan (bony) (moderately } \\
\text { known) }\end{array}$ & Roots are eaten & N.o & $\begin{array}{l}\text { It has white roots like onions or } \\
\text { small potatoes }\end{array}$ \\
\hline $\begin{array}{l}\text { Callitriche sp. (2), little known, some } \\
\text { relate it to Lemna spp. (n.d.) }\end{array}$ & (It is eaten) (unsure, dubious) & N.o & $\begin{array}{l}\text { Stays green on mud after water } \\
\text { dries up }\end{array}$ \\
\hline $\begin{array}{l}\text { Ceratophyllum spp., Myriophyllum } \\
\text { spp. (2), well known, drezga, a kind } \\
\text { of lokvanj (moderately known) }\end{array}$ & $\begin{array}{l}\text { It is eaten in small amounts or in } \\
\text { food shortage, pigs swim to get it }\end{array}$ & N.o & $\begin{array}{l}\text { A bit spiky, a lot in the Bosut river } \\
\text { and on its shores, also in deeper } \\
\text { marshes, spreads nowadays as the } \\
\text { water is polluted }\end{array}$ \\
\hline
\end{tabular}


Table 2 (continued)

\begin{tabular}{|c|c|c|c|}
\hline $\begin{array}{l}\text { Latin name, (local frequency), } \\
\text { depth of local knowledge, folk } \\
\text { names, (depth of knowledge } \\
\text { regionally-Carpathian Basin) }\end{array}$ & $\begin{array}{l}\text { Pigs eat/don't eat (svinjars' } \\
\text { reports) }\end{array}$ & $\begin{array}{l}\text { Pigs eat/don't eat (authors' } \\
\text { observations) }\end{array}$ & $\begin{array}{l}\text { Other uses and salient features } \\
\text { (e.g. impact on pigs) reported by } \\
\text { svinjars }\end{array}$ \\
\hline $\begin{array}{l}\text { Iris pseudacorus L. (3), well known, } \\
\text { perunika (from Perunika, the wife } \\
\text { of Perun, the supreme Old Slavic } \\
\text { deity) (well known) }\end{array}$ & $\begin{array}{l}\text { Roots are eaten in summer, late } \\
\text { autumn and winter when there is } \\
\text { no water in the marshes, leaves are } \\
\text { not eaten, flowers are not eaten }\end{array}$ & Leaves: nibbled regularly, roots: n.o & $\begin{array}{l}\text { Roots are grown together like pota- } \\
\text { toes (in a chain), has reddish seeds }\end{array}$ \\
\hline $\begin{array}{l}\text { Lemna spp., Spirodela polyrhiza } \\
\text { (L.) Schleid. (2), well known, sočica } \\
\text { (lentil), sočivica (lentil) (well known) }\end{array}$ & $\begin{array}{l}\text { It is eaten from the water surface, } \\
\text { pigs also swim for it in Bosut }\end{array}$ & $\begin{array}{l}\text { It was eaten eagerly, for several } \\
\text { minutes }\end{array}$ & $\begin{array}{l}\text { In marshes, may cover the whole } \\
\text { water surface, bad for the fish (less } \\
\text { oxygen), survives on the mud, deer } \\
\text { and cattle eat it }\end{array}$ \\
\hline $\begin{array}{l}\text { Marsilea quadrifolia L. (1), little } \\
\text { known, barska detelina (marsh } \\
\text { clover) (n.d.) }\end{array}$ & $\begin{array}{l}\text { (It is eaten but only a bit) (It is not } \\
\text { eaten) }\end{array}$ & It was nibbled once & Like a four-leaf clover, not common \\
\hline $\begin{array}{l}\text { Nuphar lutea (L.) Sm. (1), moderately } \\
\text { known, žuti (yellow) lokvanj (pud- } \\
\text { dle weed) (moderately known) }\end{array}$ & $\begin{array}{l}\text { Roots are eaten (leaves and flowers } \\
\text { are eaten a bit) }\end{array}$ & N.o & $\begin{array}{l}\text { In marshes and canals, disappeared } \\
\text { from drying marshes }\end{array}$ \\
\hline $\begin{array}{l}\text { Nymphaea alba L. (1), well known, } \\
\text { beli (white) lokvanj (well known) }\end{array}$ & $\begin{array}{l}\text { Roots are eaten, (leaves and flowers } \\
\text { are eaten a bit) }\end{array}$ & N.o & Herbicides killed them off \\
\hline $\begin{array}{l}\text { Oenanthe aquatica (L.) Poir. (1), little } \\
\text { known, a kind of kukuta (Conium) } \\
\text { (little known) }\end{array}$ & It is eaten (It is not eaten) & $\begin{array}{l}\text { It was regularly eaten (also in } \\
\text { winter) }\end{array}$ & \\
\hline $\begin{array}{l}\text { Potamogeton spp. (2), little known, } \\
\text { drzega, a kind of lokvanj (little } \\
\text { known) }\end{array}$ & It is not eaten & N.o & \\
\hline $\begin{array}{l}\text { Rorippa amphibia (L.) Besser (2), little } \\
\text { known (little known) }\end{array}$ & N.d & $\begin{array}{l}\text { It is eaten (young and older leaves } \\
\text { as well), even from below the water }\end{array}$ & \\
\hline $\begin{array}{l}\text { Trapa natans L. (1), well known, rašak, } \\
\text { orašak (little walnut), fruit: krava } \\
\text { (cow), šišarka (pine cone) (well } \\
\text { known) }\end{array}$ & $\begin{array}{l}\text { Green and ripe fruits are eaten with } \\
\text { pleasure, pigs swim for it, even eat } \\
\text { fruits from last year, dried black } \\
\text { fruits are not eaten, roots are eaten, } \\
\text { leaves are less eaten }\end{array}$ & N.o & $\begin{array}{l}\text { In deep water, extinct here, pigs } \\
\text { fatten on the fruits, inside: like a } \\
\text { hazelnut, edible for humans, painful } \\
\text { for bare feet }\end{array}$ \\
\hline \multicolumn{4}{|l|}{ Grasses and sedges } \\
\hline $\begin{array}{l}\text { Agrostis stolonifera L. (3), well known, } \\
\text { mekuša (softy) (well known) }\end{array}$ & It is often eaten and all year round & $\begin{array}{l}\text { It was often and patiently (for } \\
5-10 \text { min) eaten all year round, } \\
\text { a basic forage in summer and } \\
\text { autumn }\end{array}$ & $\begin{array}{l}\text { Grows in and around marshes, } \\
\text { regrows and green also in autumn }\end{array}$ \\
\hline $\begin{array}{l}\text { Brachypodium sylvaticum (Huds.) P. } \\
\text { Beauv. (4), little known (n.d.) }\end{array}$ & It is nibbled & It was nibbled & Soft \\
\hline $\begin{array}{l}\text { Carex elata All. (1), well known, šaš } \\
\text { (well known) }\end{array}$ & $\begin{array}{l}\text { It is eaten less often than other } \\
\text { marsh sedges, only if in need, roots } \\
\text { are not eaten }\end{array}$ & N.o & $\begin{array}{l}\text { Grows like Juncus (= tussocky), } \\
\text { deer eat it }\end{array}$ \\
\hline $\begin{array}{l}\text { Carex riparia Curtis, C. vesicaria L. (3), } \\
\text { well known, šaš, there are different } \\
\text { types (well known) }\end{array}$ & $\begin{array}{l}\text { Roots are eaten especially in winter } \\
\text { when they are'ripe', pigs suck out } \\
\text { 'vitamins' and 'juice,' green and } \\
\text { young leaves are eaten in winter, } \\
\text { especially in deep snow, they eat } \\
\text { to eat something, it goes through } \\
\text { them (undigested) }\end{array}$ & $\begin{array}{l}\text { Roots and leaves were eaten, } \\
\text { especially in winter, } 10-30 \mathrm{~cm} \text { long } \\
\text { roots were uprooted and chewed } \\
\text { for 2-3 min }\end{array}$ & $\begin{array}{l}\text { Grows in marshes, people used to } \\
\text { make ropes for wheat harvest, used } \\
\text { as hut roof, leaves cut your finger, } \\
\text { fruits are rare, red deer eat it }\end{array}$ \\
\hline $\begin{array}{l}\text { Carex sylvatica Huds., C. remota L., C. } \\
\text { divulsa Stokes }(2+2+3), \text { moder- } \\
\text { ately known, sitni (small) šaš, trava } \\
\text { (grass), štitasit (little known) }\end{array}$ & $\begin{array}{l}\text { It is eaten if other greens are dry in } \\
\text { autumn and spring, and especially } \\
\text { in snow, it is not eaten in summer }\end{array}$ & $\begin{array}{l}\text { It was eaten but not intensively, } \\
\text { sometimes a whole tussock, only } \\
\text { nibbled in summer }\end{array}$ & $\begin{array}{l}\text { Grows in forest, this is a kind of } \\
\text { forest grass }\end{array}$ \\
\hline $\begin{array}{l}\text { Cynodon dactylon (L.) Pers. (1), well } \\
\text { known, zubača (toothy), there are } \\
\text { two kinds if it (well known) }\end{array}$ & $\begin{array}{l}\text { Roots are eaten, especially in } \\
\text { winter, also leaves, young leaves are } \\
\text { preferred }\end{array}$ & N.o & $\begin{array}{l}\text { On arable land, on road verges and } \\
\text { pastures, less in forests, resistant } \\
\text { to herbicides, can revive itself after } \\
7 \text { years spent in the attic }\end{array}$ \\
\hline
\end{tabular}


Table 2 (continued)

\begin{tabular}{|c|c|c|c|}
\hline $\begin{array}{l}\text { Latin name, (local frequency), } \\
\text { depth of local knowledge, folk } \\
\text { names, (depth of knowledge } \\
\text { regionally-Carpathian Basin) }\end{array}$ & $\begin{array}{l}\text { Pigs eat/don't eat (svinjars' } \\
\text { reports) }\end{array}$ & $\begin{array}{l}\text { Pigs eat/don't eat (authors' } \\
\text { observations) }\end{array}$ & $\begin{array}{l}\text { Other uses and salient features } \\
\text { (e.g. impact on pigs) reported by } \\
\text { svinjars }\end{array}$ \\
\hline $\begin{array}{l}\text { Deschampsia cespitosa (L.) P. Beauv. } \\
\text { (1), little known (little-moderately } \\
\text { known) }\end{array}$ & It is eaten, also in winter & N.o & \\
\hline $\begin{array}{l}\text { Echinochloa crus-galli (L.) P. Beauv. (2), } \\
\text { moderately known, sirak, divlji sirak } \\
\text { (wild sorghum) kind of muhar (well } \\
\text { known) }\end{array}$ & It is eaten when fresh & N.o & $\begin{array}{l}\text { Grows in corn fields, but also in } \\
\text { forests in open wet places }\end{array}$ \\
\hline $\begin{array}{l}\text { Eleocharis palustris (L.) R. Br. (2), little } \\
\text { known, sita (tie), a kind of sita } \\
\text { (moderately known) }\end{array}$ & Roots are eaten in winter & Was only nibbled, roots: n.o & \\
\hline $\begin{array}{l}\text { Elytrigia repens (L.) Nevski (1), well } \\
\text { known, zubača (toothy), pirevina, } \\
\text { there are two kinds of it (well } \\
\text { known) }\end{array}$ & $\begin{array}{l}\text { Roots are eaten especially in winter, } \\
\text { also the leaves, collected from fields } \\
\text { and given to forest pigs }\end{array}$ & N.o & $\begin{array}{l}\text { Weed in arable land, less in the } \\
\text { forest, survives even if kept in the } \\
\text { chimney for } 9 \text { years, resistant to } \\
\text { herbicides }\end{array}$ \\
\hline $\begin{array}{l}\text { Glyceria fluitans (L.) R. Br. (2), little } \\
\text { known (related to Agrostis) (little } \\
\text { known) }\end{array}$ & It is eaten regularly & $\begin{array}{l}\text { It was often grazed all year round } \\
\text { and patiently for minutes, in dry } \\
\text { and also in water-logged marshes }\end{array}$ & Grows in marshes \\
\hline $\begin{array}{l}\text { Glyceria maxima (Hartm.) Holmbg. } \\
\text { (3), moderately known, sometimes } \\
\text { part of the Carex taxon (little } \\
\text { known) }\end{array}$ & Roots are eaten, also leaves & Leaves were regularly eaten & $\begin{array}{l}\text { By grazing on it, pigs compensate } \\
\text { the effects of acorn (acorn is a } \\
\text { heavy food), red deer eat it }\end{array}$ \\
\hline $\begin{array}{l}\text { Juncus effusus L. (2), well known, sita, } \\
\text { there are different kinds of sita (tall } \\
\text { and small) (moderately known) }\end{array}$ & $\begin{array}{l}\text { Roots are eaten in winter, whole } \\
\text { plants may be uprooted, leaves are } \\
\text { rarely eaten, in snowy winter and } \\
\text { when fresh, eaten by pigs in need, } \\
\text { i.e. who are not fed properly with } \\
\text { corn }\end{array}$ & It was avoided or nibbled, roots: n.o & $\begin{array}{l}\text { Not useful, it was used in the past } \\
\text { to seal gaps between boat planks }\end{array}$ \\
\hline $\begin{array}{l}\text { Leersia oryzoides (L.) Sw. (1), not } \\
\text { known (n.d.) }\end{array}$ & N.d & It was eaten several times & \\
\hline $\begin{array}{l}\text { Lolium perenne L. (2), well known, } \\
\text { muhar, vlasulja (with long hairs), } \\
\text { uncertain names (well known) }\end{array}$ & $\begin{array}{l}\text { It is eaten when young, less when } \\
\text { in flower }\end{array}$ & N.o & $\begin{array}{l}\text { On fields and meadows, along } \\
\text { roads, in 4-5-years-old clover fields, } \\
\text { tame/sweet grass, cattle and sheep } \\
\text { like it, also dogs }\end{array}$ \\
\hline $\begin{array}{l}\text { Phragmites australis (Cav.) Steud. (2), } \\
\text { well known, trska (well known) }\end{array}$ & $\begin{array}{l}\text { Maybe would be eaten (not occur- } \\
\text { ring in the local study area) }\end{array}$ & N.o & $\begin{array}{l}\text { Needs water, there is none here, } \\
\text { there were more in the past, } \\
\text { farrowing sows liked to hide in it } \\
\text { (protection from jackals and foxes), } \\
\text { used for roofs, water is drinkable in } \\
\text { reed beds }\end{array}$ \\
\hline $\begin{array}{l}\text { Poa pratensis L., P. trivialis L. }(2+2), \\
\text { little known (moderately known) }\end{array}$ & It is eaten when fresh & It was eaten several times & \\
\hline $\begin{array}{l}\text { Schoenoplectus lacustris (L.) Palla (2), } \\
\text { well known,'prava' (real) siita (well } \\
\text { known) }\end{array}$ & $\begin{array}{l}\text { Roots are eaten in summer, even } \\
\text { under water, in soft mud, but also } \\
\text { in winter, especially if there are no } \\
\text { acorns, leaves are not eaten }\end{array}$ & It was regularly avoided & $\begin{array}{l}\text { It lives in water, good for baskets, } \\
\text { bad as roofing, has small brown } \\
\text { flowers on the top }\end{array}$ \\
\hline $\begin{array}{l}\text { Setaria spp. (2), well known, mu'ar, } \\
\text { krpiguz (ass patching), bodljikavo } \\
\text { prase (spiny piglet, meaning } \\
\text { hedgehog) (well known) }\end{array}$ & $\begin{array}{l}\text { It is eaten when young, we grazed } \\
\text { it in summer in the past }\end{array}$ & N.o & $\begin{array}{l}\text { Grows in the fields, not in the forest, } \\
\text { sticks to clothes (only the seeds) }\end{array}$ \\
\hline $\begin{array}{l}\text { Sorghum halepense (L.) Pers. (1), well } \\
\text { known (well known) }\end{array}$ & It is not eaten & N.o & Total herbicide is used against it \\
\hline
\end{tabular}


Table 2 (continued)

\begin{tabular}{|c|c|c|c|}
\hline $\begin{array}{l}\text { Latin name, (local frequency), } \\
\text { depth of local knowledge, folk } \\
\text { names, (depth of knowledge } \\
\text { regionally-Carpathian Basin) }\end{array}$ & $\begin{array}{l}\text { Pigs eat/don't eat (svinjars' } \\
\text { reports) }\end{array}$ & $\begin{array}{l}\text { Pigs eat/don't eat (authors' } \\
\text { observations) }\end{array}$ & $\begin{array}{l}\text { Other uses and salient features } \\
\text { (e.g. impact on pigs) reported by } \\
\text { svinjars }\end{array}$ \\
\hline $\begin{array}{l}\text { Typha angustifolia L., T. latifolia L. } \\
(1+1) \text {, well known, rogoz (horny), } \\
\text { spike: keka, palčika (stick), palačka } \\
\text { (well known) }\end{array}$ & $\begin{array}{l}\text { Roots are eaten / roots are not } \\
\text { eaten (contradicting reports) }\end{array}$ & N.o & $\begin{array}{l}\text { Grows in water, in canals, non- } \\
\text { flowering individuals were used } \\
\text { for ropes (strong, wide leaves and } \\
\text { doesn't cut like sedge), for sealing } \\
\text { barrels, ornamental, children's toy }\end{array}$ \\
\hline \multicolumn{4}{|l|}{ Other generalist dicotyledons } \\
\hline $\begin{array}{l}\text { Allium scorodoprasum L. (1), moder- } \\
\text { ately known, luk (well known) }\end{array}$ & N.d & N.o & Smells like onion or garlic, edible \\
\hline $\begin{array}{l}\text { Althaea officinalis L. (2), well known, } \\
\text { beli (white) slez (well known) }\end{array}$ & It is not eaten & Small bits were nibbled & $\begin{array}{l}\text { In wet places, medicinal, collected } \\
\text { for sale }\end{array}$ \\
\hline $\begin{array}{l}\text { Ambrosia artemisiifolia L. (2), well } \\
\text { known, ambrozija (well known) }\end{array}$ & It is not eaten & N.o & $\begin{array}{l}\text { Causes allergy, has a bad smell, } \\
\text { a bad weed, doesn't grow in the } \\
\text { shade, sheep and goats eat it }\end{array}$ \\
\hline $\begin{array}{l}\text { Anthriscus cerefolium (L.) Hoffm. } \\
\text { (2), little known, a sort of kukuta } \\
\text { (Conium) or peršun (Petroselinum) } \\
\text { (little known) }\end{array}$ & It is not eaten & N.o & \\
\hline $\begin{array}{l}\text { Arctium lappa L. (2), well known, } \\
\text { repuh, veliki cičcak (big bur with } \\
\text { hooks, big sticking bur) (well } \\
\text { known) }\end{array}$ & $\begin{array}{l}\text { Leaves are eaten but only in very } \\
\text { early spring, roots are eaten in } \\
\text { winter }\end{array}$ & Plants were avoided & $\begin{array}{l}\text { In sparse forests, children use it as } \\
\text { an umbrella and throw burs into } \\
\text { girls' hair, medicinal, deer eat it }\end{array}$ \\
\hline $\begin{array}{l}\text { Asclepias syriaca L. (2), well known, } \\
\text { divlji pamuk (wild cotton) (well } \\
\text { known) }\end{array}$ & It is not eaten & N.o & $\begin{array}{l}\text { Along roads and dykes, honey } \\
\text { plant, stalks are bad in hay }\end{array}$ \\
\hline $\begin{array}{l}\text { Astragalus glycyphyllos L. (2), little } \\
\text { known (little known) }\end{array}$ & It is not eaten & It was not eaten & Not even goats eat it \\
\hline $\begin{array}{l}\text { Ballota nigra L. (3), moderately } \\
\text { known, relative of mrtva žara } \\
\text { (dead ember), mrtva kopriva (dead } \\
\text { nettle) (=Lamium sp.) (moderately } \\
\text { known) }\end{array}$ & $\begin{array}{l}\text { It is nibbled a bit in need when } \\
\text { young }\end{array}$ & N.o & $\begin{array}{l}\text { Smaller than the nettle, honey } \\
\text { plant, it is used for catching wild } \\
\text { (and fleeing) bees by its smell }\end{array}$ \\
\hline $\begin{array}{l}\text { Bidens tripartitus L., B. frondosus L. (3), } \\
\text { well known, viljuščica (small fork), } \\
\text { mali čičak (small bur with hooks) } \\
\text { (well known) }\end{array}$ & It is eaten when young & $\begin{array}{l}\text { Whole plants were eaten when } \\
\text { fresh, incl. flowers and young fruits }\end{array}$ & $\begin{array}{l}\text { Grows in abandoned wet places, } \\
\text { easily sticks to clothes }\end{array}$ \\
\hline $\begin{array}{l}\text { Caltha palustris L. (1), well known, } \\
\text { type of ljutić (spicy) (well known) }\end{array}$ & It is not eaten, pigs walk across it & It was not eaten & Grows in marshes, has star-like fruits \\
\hline $\begin{array}{l}\text { Calystegia sepium (L.) R. Br. (1), well } \\
\text { known, poponac (climber), forms a } \\
\text { folk taxon with but distinguished } \\
\text { morphologically from Convolvulus } \\
\text { (well known) }\end{array}$ & It is eaten & N.o & $\begin{array}{l}\text { Grows in weedy arable fields, in } \\
\text { marshes, rare in forests }\end{array}$ \\
\hline $\begin{array}{l}\text { Cardamine pratensis L. (2), moderately } \\
\text { known, name not remembered } \\
\text { (n.d.) }\end{array}$ & $\begin{array}{l}\text { It is not eaten, rarely nibbled when } \\
\text { young }\end{array}$ & $\begin{array}{l}\text { It was both nibbled and avoided } \\
\text { several times }\end{array}$ & It is rare in the forest \\
\hline $\begin{array}{l}\text { Chaiturus (Leonurus) marrubiastrum } \\
\text { Ehrh. ex Rchb. (1), little known (n.d.) }\end{array}$ & (Rarely nibbled a bit) & It was not eaten & \\
\hline $\begin{array}{l}\text { Chenopodium album L., Lipandra } \\
\text { polysperma (L.) S. Fuentes \& al. } \\
(2+2) \text {, well known, zelje (greeny, } \\
\text { a common name for juicy leafy } \\
\text { weeds) (well known) }\end{array}$ & $\begin{array}{l}\text { It is eaten when fresh, but also the } \\
\text { seeds, it was often collected for } \\
\text { green fodder in the past for home } \\
\text { and forest pigs, causes diarrhoea to } \\
\text { home-kept pigs }\end{array}$ & N.o & $\begin{array}{l}\text { Grows in arable fields, rare in for- } \\
\text { ests, mostly in former fodder places, } \\
\text { all livestock like it, some people eat } \\
\text { it cooked }\end{array}$ \\
\hline $\begin{array}{l}\text { Cichorium intybus L. (2), well known, } \\
\text { name not remembered, a korov } \\
\text { (weed) (well known) }\end{array}$ & It is not eaten & N.o & $\begin{array}{l}\text { In fields, along roads, not in forests, } \\
\text { medicinal, honey plant }\end{array}$ \\
\hline
\end{tabular}


Table 2 (continued)

\begin{tabular}{|c|c|c|c|}
\hline $\begin{array}{l}\text { Latin name, (local frequency), } \\
\text { depth of local knowledge, folk } \\
\text { names, (depth of knowledge } \\
\text { regionally-Carpathian Basin) }\end{array}$ & $\begin{array}{l}\text { Pigs eat/don't eat (svinjars' } \\
\text { reports) }\end{array}$ & $\begin{array}{l}\text { Pigs eat/don't eat (authors' } \\
\text { observations) }\end{array}$ & $\begin{array}{l}\text { Other uses and salient features } \\
\text { (e.g. impact on pigs) reported by } \\
\text { svinjars }\end{array}$ \\
\hline $\begin{array}{l}\text { Cirsium arvense (L.) Scop. (2), well } \\
\text { known, 'prava' (the real) boca } \\
\text { (spiny), čičak (sticking bur), } \\
\text { palamida (well known) }\end{array}$ & $\begin{array}{l}\text { It is eaten only when young, flowers } \\
\text { are not eaten, maybe roots are also } \\
\text { eaten }\end{array}$ & N.o & $\begin{array}{l}\text { Noxious weed, rare in forests, } \\
\text { honey plant }\end{array}$ \\
\hline $\begin{array}{l}\text { Cirsium vulgare (Savi) Ten., Carduus } \\
\text { acanthoides L. (1+1), moderately } \\
\text { known, magareća/magarca trava } \\
\text { (donkey grass), čičak (sticking bur), } \\
\text { boca (pricker) (well known) }\end{array}$ & It is eaten only when young & N.o & \\
\hline $\begin{array}{l}\text { Convolvulus arvensis L. (2), well } \\
\text { known, poponac (climber), forms a } \\
\text { taxon with but distinguished from } \\
\text { Calystegia, slatkovina (sweet), slatkiš } \\
\text { (candy) (well known) }\end{array}$ & It is eaten & N.o & In arable fields, rare in forests \\
\hline $\begin{array}{l}\text { Dipsacus fullonum L. (1), well known, } \\
\text { češlja (comb) (well known) }\end{array}$ & It is not eaten & N.o & $\begin{array}{l}\text { In abandoned places, not in the for- } \\
\text { est, you can drink from it, nothing } \\
\text { eats it, honey plant }\end{array}$ \\
\hline $\begin{array}{l}\text { Erigeron annuus (L.) Desf. (2), little } \\
\text { known (n.d.) }\end{array}$ & (It is not eaten) & It was eaten regularly & \\
\hline $\begin{array}{l}\text { Euphorbia spp. (2), well known, } \\
\text { mlečika (milkweed), several types, } \\
\text { species are not well distinguished, } \\
\text { kind of paprat (well known) }\end{array}$ & It is not eaten & (It was not eaten) & It leaks milk when broken \\
\hline $\begin{array}{l}\text { Fragaria vesca L. (2), well known, } \\
\text { divlja jagoda (wild strawberry) (well } \\
\text { known) }\end{array}$ & $\begin{array}{l}\text { Fruits are eaten (but is not an } \\
\text { important forage), leaves are not } \\
\text { eaten }\end{array}$ & N.o & $\begin{array}{l}\text { Grows in drier sunnier places, fruits } \\
\text { are eaten by people, smells good, } \\
\text { wild boar avoids its fruits, used for } \\
\text { slatko (fruit put into sweet syrup) }\end{array}$ \\
\hline $\begin{array}{l}\text { Galium aparine L. (2), well known, } \\
\text { krpiguz (ass patching), prilepača } \\
\text { (sticks to), čičak (sticking bur) (well } \\
\text { known) }\end{array}$ & It is not eaten & N.o & Sticks to you \\
\hline $\begin{array}{l}\text { Genista tinctoria L. (1), little known } \\
\text { (n.d.) }\end{array}$ & It is not eaten & N.o & $\begin{array}{l}\text { Along forest roads, deer eat it, not a } \\
\text { tree but not a herb either }\end{array}$ \\
\hline $\begin{array}{l}\text { Geranium spp. (annual spp.) (2), little } \\
\text { known (moderately known) }\end{array}$ & Unsure & It was not eaten & \\
\hline $\begin{array}{l}\text { Glechoma hederacea L. (4), little } \\
\text { known, it has no local name (n.d.) }\end{array}$ & It is not eaten, only rarely eaten & $\begin{array}{l}\text { Leaves were regularly eaten but } \\
\text { only for }<1-2 \mathrm{~min} \text {, sometimes also } \\
\text { the roots }\end{array}$ & Too small for us to see... \\
\hline $\begin{array}{l}\text { Humulus lupulus L. (1), well known, } \\
\text { hmelj (well known) }\end{array}$ & It is not eaten & N.o & Climbing plant \\
\hline $\begin{array}{l}\text { Hypericum hirsutum L., H. tetrapterum } \\
\text { Fr. }(1+2) \text {, little known (well known) }\end{array}$ & (It is eaten) & It was eaten & \\
\hline $\begin{array}{l}\text { Lamium purpureum L. (2), well } \\
\text { known, mrtva kopriva (dead nettle), } \\
\text { mrtva žara (dead ember) (well } \\
\text { known) }\end{array}$ & $\begin{array}{l}\text { It is eaten when young, pigs are not } \\
\text { keen on it, don't adore it }\end{array}$ & N.o & $\begin{array}{l}\text { In open places, not in forest, honey } \\
\text { plant }\end{array}$ \\
\hline $\begin{array}{l}\text { Lathyrus tuberosus L., L. pratensis L. } \\
\qquad(1+1) \text {, well known, divlji grašak } \\
\text { (wild pea) (well known) }\end{array}$ & It is eaten & N.o & $\begin{array}{l}\text { In arable fields and clear cuts, } \\
\text { climbing plant, cattle also eat it } \\
\text { (bulbs were not eaten by children) }\end{array}$ \\
\hline $\begin{array}{l}\text { Linaria vulgaris Mill. (2), little known, } \\
\text { name not remembered (moder- } \\
\text { ately known) }\end{array}$ & (It is not eaten) & N.o & $\begin{array}{l}\text { In grasslands, we played with it } \\
\text { (open-close) }\end{array}$ \\
\hline $\begin{array}{l}\text { Lycopus europaeus L., L. exaltatus L. Fil. } \\
(2+2) \text {, not known (little known) }\end{array}$ & N.d & $\begin{array}{l}\text { It was not eaten, was avoided, nib- } \\
\text { bled once }\end{array}$ & \\
\hline $\begin{array}{l}\text { Lysimachia nummularia L. (3), little } \\
\text { known (n.d.) }\end{array}$ & $\begin{array}{l}\text { (Usually it is not eaten, leaves and } \\
\text { roots are eaten rarely) }\end{array}$ & $\begin{array}{l}\text { It was eaten, also avoided, roots } \\
\text { were also eaten }\end{array}$ & In wet places \\
\hline
\end{tabular}


Table 2 (continued)

\begin{tabular}{|c|c|c|c|}
\hline $\begin{array}{l}\text { Latin name, (local frequency), } \\
\text { depth of local knowledge, folk } \\
\text { names, (depth of knowledge } \\
\text { regionally-Carpathian Basin) }\end{array}$ & $\begin{array}{l}\text { Pigs eat/don't eat (svinjars' } \\
\text { reports) }\end{array}$ & $\begin{array}{l}\text { Pigs eat/don't eat (authors' } \\
\text { observations) }\end{array}$ & $\begin{array}{l}\text { Other uses and salient features } \\
\text { (e.g. impact on pigs) reported by } \\
\text { svinjars }\end{array}$ \\
\hline $\begin{array}{l}\text { Lythrum salicaria L. (2), moderately } \\
\text { known (little known) }\end{array}$ & It is not eaten & N.o & In marshes and canals \\
\hline $\begin{array}{l}\text { Melilotus albus Medik. (2), moderately } \\
\text { known, divlja detelina (wild clover), } \\
\text { smrdljan (smelly) (well known) }\end{array}$ & It is not eaten & N.o & \\
\hline $\begin{array}{l}\text { Mentha aquatica L., M. Iongifolia (L.) L. } \\
(3+1) \text {, well known, konjski bosiljak } \\
\text { (horse basil), the two species are } \\
\text { partly distinguished (well known) }\end{array}$ & It is not eaten (rarely nibbled) & It was not eaten, nibbled once & $\begin{array}{l}\text { In margins of marshes, honey plant, } \\
\text { has a good and strong smell, good } \\
\text { for tea, useful against mosquitos }\end{array}$ \\
\hline $\begin{array}{l}\text { Myosotis scorpioides L. (2), little } \\
\text { known (moderately known) }\end{array}$ & It is not eaten & N.o & \\
\hline $\begin{array}{l}\text { Persicaria dubia (P. mite) (Stein) Fourr. } \\
\text { (4), well known, divlja paprika (wild } \\
\text { pepper), paprat (meaning a useless } \\
\text { plant) (moderately known) }\end{array}$ & $\begin{array}{l}\text { It is eaten if no better is available, } \\
\text { e.g. in drought, or while fresh, on } \\
\text { sunny spots }\end{array}$ & $\begin{array}{l}\text { It was eaten regularly, but more } \\
\text { often avoided, after smelling }\end{array}$ & $\begin{array}{l}\text { In wetter places, spicy, plants like } P \text {. } \\
\text { dubia age later as they live in wet } \\
\text { places }\end{array}$ \\
\hline $\begin{array}{l}\text { Physalis alkekengi L. (2), well known, } \\
\text { gujina or divlja jabučica/jabuka } \\
\text { (snake or wild apple) (well known) }\end{array}$ & It is not eaten & It was not eaten & $\begin{array}{l}\text { We like and eat it, very healthy, } \\
\text { if red, full of vitamin C, one berry } \\
\text { equals one-two lemons, sour-bitter, } \\
\text { it is sold in shops }\end{array}$ \\
\hline $\begin{array}{l}\text { Phytolacca americana L. (1), well } \\
\text { known, name not remembered } \\
\text { (n.d.) }\end{array}$ & It is not eaten & N.o & $\begin{array}{l}\text { Grows along roads, has a hollow } \\
\text { red stem }\end{array}$ \\
\hline $\begin{array}{l}\text { Plantago major L. (3), well known, } \\
\text { bokvica (well known) }\end{array}$ & $\begin{array}{l}\text { It is eaten (while fresh) (It is not } \\
\text { eaten) }\end{array}$ & N.o & Medicinal for wounds \\
\hline $\begin{array}{l}\text { Polygonum aviculare L. (3), well } \\
\text { known, troskot, troskut, troskoč, } \\
\text { troskovača (well known) }\end{array}$ & $\begin{array}{l}\text { It is loved by pigs, cannot grow } \\
\text { fully, it is eaten up, it is eaten less } \\
\text { when it is older }\end{array}$ & It was eaten eagerly & $\begin{array}{l}\text { On (dirt) roads, in yards, creeping } \\
\text { on the ground }\end{array}$ \\
\hline $\begin{array}{l}\text { Potentilla reptans L. (2), well known, } \\
\text { like jagodnjak (strawberry), riblja } \\
\text { trava (fish grass) (moderately } \\
\text { known) }\end{array}$ & It is eaten eagerly & (It was not eaten) & $\begin{array}{l}\text { In flooded grasslands, similar to } \\
\text { Fragaria but with no fruits }\end{array}$ \\
\hline $\begin{array}{l}\text { Ranunculus repens L. (3), moderately } \\
\text { known, often has no name, ljutić } \\
\text { (spicy), barska trava (marsh grass) } \\
\text { (moderately known) }\end{array}$ & It is not eaten, rarely nibbled & It was not eaten, nibbled once & $\begin{array}{l}\text { In wet places in villages and } \\
\text { marshes, leaves used as painted } \\
\text { Easter egg pattern }\end{array}$ \\
\hline $\begin{array}{l}\text { Ranunculus sceleratus L. (2), little } \\
\text { known, has no name, barska trava } \\
\text { (marsh grass) (little known) }\end{array}$ & It is not eaten, rarely nibbled & It was not eaten & Poisonous, bloats up pigs \\
\hline $\begin{array}{l}\text { Rumex crispus L., } R \text {. patientia L. }(1+1) \text {, } \\
\text { moderately known (well known) }\end{array}$ & It is eaten if fresh & N.o & $\begin{array}{l}\text { Healthy food for pigs, good against } \\
\text { diarrhoea }\end{array}$ \\
\hline $\begin{array}{l}\text { Sambucus ebulus L. (1), well known, } \\
\text { apta (well known) }\end{array}$ & $\begin{array}{l}\text { It is not eaten, pigs just walk across } \\
\text { it }\end{array}$ & It was not eaten & $\begin{array}{l}\text { In open places, poisonous, used for } \\
\text { making valuable brandy (rakija, sold } \\
\text { as alga), jam, against fleas, deer and } \\
\text { cattle eat }\end{array}$ \\
\hline $\begin{array}{l}\text { Solanum dulcamara L. (2), little } \\
\text { known, kereće grožđe (dog grape) } \\
\text { (little known) }\end{array}$ & $\begin{array}{l}\text { It is not eaten, maybe too bitter for } \\
\text { them }\end{array}$ & N.o & I have never tasted the fruits \\
\hline $\begin{array}{l}\text { Solidago gigantea Aiton (2), well } \\
\text { known, name not remembered } \\
\text { (paprat) (well kown) }\end{array}$ & It is not eaten & N.o & $\begin{array}{l}\text { Grows in large patches, around } \\
\text { marshes, a honey plant }\end{array}$ \\
\hline $\begin{array}{l}\text { Sonchus arvensis L., S. asper (L.) Hill. } \\
(2+2) \text {, well known, 'prava' (the real) } \\
\text { mlečika (milkish), mlečac (milky), a } \\
\text { kind of boca (spiny) (well known) }\end{array}$ & $\begin{array}{l}\text { It is eaten, pigs love it, especially } \\
\text { when young, less if too spiny, col- } \\
\text { lected as fresh green fodder }\end{array}$ & N.o & $\begin{array}{l}\text { It leaks milk when cut, also col- } \\
\text { lected for other livestock (e.g. } \\
\text { sheep, rabbit) }\end{array}$ \\
\hline
\end{tabular}


Table 2 (continued)

\begin{tabular}{|c|c|c|c|}
\hline $\begin{array}{l}\text { Latin name, (local frequency), } \\
\text { depth of local knowledge, folk } \\
\text { names, (depth of knowledge } \\
\text { regionally-Carpathian Basin) }\end{array}$ & $\begin{array}{l}\text { Pigs eat/don't eat (svinjars' } \\
\text { reports) }\end{array}$ & $\begin{array}{l}\text { Pigs eat/don't eat (authors' } \\
\text { observations) }\end{array}$ & $\begin{array}{l}\text { Other uses and salient features } \\
\text { (e.g. impact on pigs) reported by } \\
\text { svinjars }\end{array}$ \\
\hline $\begin{array}{l}\text { Stellaria media (L.) Cirillo (2), well } \\
\text { known, mišovkinja (mouse grass) } \\
\text { (well known) }\end{array}$ & It is eaten & (It was eaten/ was avoided) & $\begin{array}{l}\text { In arable land, on black soil, in } \\
\text { Robinia plantations, all type of } \\
\text { livestock like it }\end{array}$ \\
\hline $\begin{array}{l}\text { Symphytum officinale L. (2), well } \\
\text { known, name not remembered } \\
\text { (well known) }\end{array}$ & $\begin{array}{l}\text { Only the roots are eaten (leaves are } \\
\text { not eaten) }\end{array}$ & N.o & $\begin{array}{l}\text { Medicinal, nectar is a children's } \\
\text { snack }\end{array}$ \\
\hline $\begin{array}{l}\text { Tanacetum vulgare L. (3), well known, } \\
\text { smrdjlak/ smrdjlan (smelly), a type } \\
\text { of paprat (meaning a kind of } \\
\text { weed), type of korov (weed) (mod- } \\
\text { erately known) }\end{array}$ & It is not eaten & It was not eaten & $\begin{array}{l}\text { Around marshes, but not in the } \\
\text { water, it is smelly, poisonous, it is } \\
\text { like a broom, rubbed on the skin } \\
\text { against mosquitos }\end{array}$ \\
\hline $\begin{array}{l}\text { Taraxacum officinale aggr. (3), well } \\
\text { known, maslačak (name refers to } \\
\text { butter and lard) (well known) }\end{array}$ & $\begin{array}{l}\text { Leaves are eaten before blooming, } \\
\text { pigs like it very much }\end{array}$ & It was eaten several times & $\begin{array}{l}\text { Milky, young leaves good for salad } \\
\text { (but ham is a better 'salad'...), flow- } \\
\text { ers soaked in water to make honey, } \\
\text { root is medicinal }\end{array}$ \\
\hline $\begin{array}{l}\text { Trifolium pratense L. (1), well known, } \\
\text { divlja detelina (wild clover), there } \\
\text { are 2-3 types (well known) }\end{array}$ & $\begin{array}{l}\text { It is eaten when young, i.e. also in } \\
\text { autumn, pigs like it }\end{array}$ & N.o & $\begin{array}{l}\text { Doesn't grow everywhere, veteri- } \\
\text { narians argue that it is not good } \\
\text { for pigs }\end{array}$ \\
\hline $\begin{array}{l}\text { Trifolium repens L. (1), well known, } \\
\text { divlja detelina (wild clover) (well } \\
\text { known) }\end{array}$ & $\begin{array}{l}\text { It is eaten when young, i.e. also in } \\
\text { autumn }\end{array}$ & It was eaten several times & \\
\hline $\begin{array}{l}\text { Tussilago farfara L. (1), moderately } \\
\text { known, podelj, podbelj (white } \\
\text { below) (well known) }\end{array}$ & It is not eaten & N.o & $\begin{array}{l}\text { Grows mostly on dykes and at } \\
\text { forest edges }\end{array}$ \\
\hline $\begin{array}{l}\text { Urtica dioica L. (3), well known, } \\
\text { kopriva, žara (ember, burner) (well } \\
\text { known) }\end{array}$ & $\begin{array}{l}\text { Leaves are eaten when fresh and } \\
\text { when dry, home-kept pigs eat it } \\
\text { more eagerly, eat roots in winter, if } \\
\text { in need }\end{array}$ & It was eaten once & $\begin{array}{l}\text { Stinky, medicinal and healthy, good } \\
\text { for soup and salad, but ham is } \\
\text { better... }\end{array}$ \\
\hline $\begin{array}{l}\text { Verbascum lychnitis L. (1), moderately } \\
\text { known, name not remembered } \\
\text { (well known) }\end{array}$ & $\begin{array}{l}\text { It is not eaten, a bit if cut when } \\
\text { young }\end{array}$ & N.o & Along roads, not in the forest \\
\hline $\begin{array}{l}\text { Veronica hederifolia L. (3), little known } \\
\text { (little known) }\end{array}$ & It is eaten & N.o & \\
\hline $\begin{array}{l}\text { Vicia sativa L., V. cracca L., V. sepium L. } \\
(2+1+2) \text {, well known, divlji grašak } \\
\text { (wild pea), divlja grahorica (wild } \\
\text { faba bean) (well known) }\end{array}$ & It is eaten (It is not eaten) & N.o & \\
\hline $\begin{array}{l}\text { Xanthium strumarium L. (2), well } \\
\text { known, boca (pricker), mali čičak } \\
\text { (small sticking bur) (well known) }\end{array}$ & $\begin{array}{l}\text { It is eaten at germination, at } 2-3 \\
\text { leaved stage, in first } 10 \text { days, pigs } \\
\text { love it and eat large amounts, it is } \\
\text { not eaten later }\end{array}$ & N.o & $\begin{array}{l}\text { In marshes and wet arable fields, } \\
\text { grows after water dries up, espe- } \\
\text { cially in wet years, poisonous to } \\
\text { pigs, poorly fed and hungry pigs } \\
\text { die of it by the morning (there is } \\
\text { no medicine against it), fruits stick } \\
\text { to clothes, spiny fruits used by chil- } \\
\text { dren to imitate injection needles }\end{array}$ \\
\hline \multicolumn{4}{|l|}{ Some further species } \\
\hline $\begin{array}{l}\text { Achillea spp. (2), little known, } \\
\text { hajdučka trava (outlaw`s grass) } \\
\text { (well known) }\end{array}$ & N.d & N.o & Medicinal tea, has good smell \\
\hline $\begin{array}{l}\text { Agrimonia eupatoria L. (2), well } \\
\text { known, sitni čičak (small sticking } \\
\text { bur) (well known) }\end{array}$ & It is not eaten & N.o & Medicinal tea, sticky fruits (burs) \\
\hline
\end{tabular}


Table 2 (continued)

\begin{tabular}{|c|c|c|c|}
\hline $\begin{array}{l}\text { Latin name, (local frequency), } \\
\text { depth of local knowledge, folk } \\
\text { names, (depth of knowledge } \\
\text { regionally-Carpathian Basin) }\end{array}$ & $\begin{array}{l}\text { Pigs eat/don't eat (svinjars' } \\
\text { reports) }\end{array}$ & $\begin{array}{l}\text { Pigs eat/don't eat (authors' } \\
\text { observations) }\end{array}$ & $\begin{array}{l}\text { Other uses and salient features } \\
\text { (e.g. impact on pigs) reported by } \\
\text { svinjars }\end{array}$ \\
\hline $\begin{array}{l}\text { Amaranthus retroflexus L. (2), well } \\
\text { known, štir (well known) }\end{array}$ & $\begin{array}{l}\text { Pigs like it very much, especially } \\
\text { young leaves and stem, also seeds, } \\
\text { eat till full, all year round, was often } \\
\text { collected for green fodder in the } \\
\text { past for home and forest pigs }\end{array}$ & N.o & Grows on arable land, rare in forests \\
\hline $\begin{array}{l}\text { Aristolochia clematitis L. (1), well } \\
\text { known, gujina or vučja jabučica } \\
\text { (snake/wolf apple) (well known) }\end{array}$ & It is not eaten & N.o & $\begin{array}{l}\text { Poisonous, not useful (not medici- } \\
\text { nal) }\end{array}$ \\
\hline $\begin{array}{l}\text { Bellis perennis L. (2), well known, bela } \\
\text { (white) rada (female name, giving } \\
\text { happiness), tratinčica? (growing } \\
\text { among grass) (well known) }\end{array}$ & It is not eaten & N.o & $\begin{array}{l}\text { On lawns, ruminants (incl. deer) } \\
\text { eat it }\end{array}$ \\
\hline $\begin{array}{l}\text { Chelidonium majus L. (1), little known } \\
\text { (well known) }\end{array}$ & It is not eaten & N.o & In the village \\
\hline $\begin{array}{l}\text { Clematis integrifolia L. (1), little known } \\
\text { (little known) }\end{array}$ & It is not eaten & N.o & In meadows, fragrant \\
\hline $\begin{array}{l}\text { Colchicum autumnale L. (0), little } \\
\text { known, like divlji crocus? (wild } \\
\text { crocus) (well known) }\end{array}$ & N.d & N.o & $\begin{array}{l}\text { Doesn't grow here [but common } \\
\text { on Sava dykes] }\end{array}$ \\
\hline $\begin{array}{l}\text { Conium maculatum L. (1), well } \\
\text { known, kukuta (well known) }\end{array}$ & It is not eaten & N.o & $\begin{array}{l}\text { Poisonous, young geese and } \\
\text { turkeys die from it }\end{array}$ \\
\hline $\begin{array}{l}\text { Cuscuta sp. (1), well known, vilina } \\
\text { kosa (fairy hair) (well known) }\end{array}$ & It is not eaten & N.o & In fields, not in forests, kills clover \\
\hline $\begin{array}{l}\text { Daucus carota L. (1), moderately } \\
\text { known, divlja mrkva (wild carrot), } \\
\text { stid cveće (shame flower) (well } \\
\text { known) }\end{array}$ & It is not eaten & N.o & $\begin{array}{l}\text { On black earth, not in the forest, } \\
\text { "girls lost their shame nowadays" } \\
\text { (referring to the local name of the } \\
\text { plant) }\end{array}$ \\
\hline $\begin{array}{l}\text { Equisetum arvense L. (1), moderately } \\
\text { known, name not remembered } \\
\text { (well known) }\end{array}$ & It is not eaten & N.o & $\begin{array}{l}\text { In wet places, not in the forest, it } \\
\text { has brown and green versions }\end{array}$ \\
\hline $\begin{array}{l}\text { Leucanthemum ircutianum DC. } \\
\text { (0), moderately known, kamilica } \\
\text { (chamomile) but they know it is } \\
\text { not chamomile (well known) }\end{array}$ & It is not eaten & N.o & In meadows, rare in forests \\
\hline $\begin{array}{l}\text { Matricaria discoidea DC. (1), moder- } \\
\text { ately known, divlja kamilica (wild } \\
\text { chamomile) (well known) }\end{array}$ & N.d & N.o & The small one, medicinal, fragrant \\
\hline $\begin{array}{l}\text { Rumex acetosa L. (1), well known, } \\
\text { kiseljak (tasting sour)(well known) }\end{array}$ & N.d & N.o & $\begin{array}{l}\text { In meadows that dry up by sum- } \\
\text { mer, used as a children's snack }\end{array}$ \\
\hline $\begin{array}{l}\text { Solanum nigrum L. (1), moderately } \\
\text { known, kereće grožđe (dog grape), } \\
\text { divlje grožđe (wild grape) (well } \\
\text { known) }\end{array}$ & It is not eaten & N.o & $\begin{array}{l}\text { In arable fields, blooms in autumn, } \\
\text { a honey plant, maybe useful as a } \\
\text { marihuana substitute }\end{array}$ \\
\hline $\begin{array}{l}\text { Tripleurospermum inodorum (L.) } \\
\text { Sch. Bip. (1), well known, konjska } \\
\text { kamilica (horse chamomile), smrdl- } \\
\text { jan (smelly), peršun (Petroselinum), } \\
\text { parsley (well known) }\end{array}$ & It is not eaten & N.o & $\begin{array}{l}\text { Doesn't grow in the forest, smelly, } \\
\text { taller than chamomile, bittersweet } \\
\text { (gorčarka), not medicinal, not good } \\
\text { for bees }\end{array}$ \\
\hline $\begin{array}{l}\text { Xanthium spinosum L. (1), well } \\
\text { known, dikičina rampa, čičak (sticky } \\
\text { bur), boca (pricker) (well known) }\end{array}$ & It is not eaten & N.o & $\begin{array}{l}\text { In pastures and along roads, } \\
\text { decreasing in quantity, has painful } \\
\text { spines }\end{array}$ \\
\hline
\end{tabular}

In the first column, scientific names are followed by data on frequency in the study area (4-common, 3-frequent, 2-sporadic, 1-rare, 0-missing); how well the plant is known (well, moderately, little or not known); local folk names (followed by their meaning, if known); and finally, in parentheses, the level of folk knowledge of the species in general in the Carpathian Basin (well, moderately, little or not known-based on [89, 91-93] and authors' unpublished data)

N.o. no observation on foraging or avoidance of the species, N.d. no data 
Table 3 Plant species (30) that were asked in interviews but were probably little or not known by local svinjars (no data on pig foraging was reported or observed)

\begin{tabular}{|c|c|c|c|}
\hline Species name & Occurrence in the area & $\begin{array}{l}\text { Probable level of local } \\
\text { knowledge by svinjars }\end{array}$ & Additional information \\
\hline Acer negundo L & Recently spreading in the area & Little known & - \\
\hline Alliaria petiolata (M. Bieb.) Cavara and Grande & Common in shady places & Not known & - \\
\hline Alnus glutinosa (L.) Gaertn & Probably doesn't occur any more & Not known & - \\
\hline Anemone ranunculoides $L$ & Very rare in the forest & Not known & - \\
\hline Armoracia macrocarpa (Willd.) Baumg & Rare in the marshes & Not known & - \\
\hline Asarum europaeum $L$ & Very rare in the forest & Very little known & Local name: kopitjnak \\
\hline Betula pendula Roth & Probably doesn't occur any more & Little known & Breza, in the village \\
\hline Campanula trachelium L & Moderately rare in the forest & very little known & Local name: zvončić \\
\hline Corydalis cava (L.) Schweigg. and Körte & Probably doesn't occur any more & Not known & - \\
\hline Dioscorea communis (L.) Caddick and Wilkin & Rare in the forest & Little known & - \\
\hline Frangula alnus Mill & Not rare in the forest & Very little known & - \\
\hline Galium odoratum (L.) Scop & Moderately rare in the forest & Not known & - \\
\hline Gentiana pneumonanthe L & Probably doesn't occur any more & Not known & - \\
\hline Glycyrrhiza echinata L & Not rare in open spaces & Very little known & - \\
\hline Hottonia palustris L & Very rare in the marshes & Not known & - \\
\hline Hydrocharis morsus-ranae L & Common in the marshes & Very little known & A kind of lokvanj \\
\hline Lathraea squamaria $\mathrm{L}$ & probably doesn't occur any more & Not known & - \\
\hline Lathyrus vernus (L.) Bernh & Very rare in the forest & Not known & - \\
\hline Lotus corniculatus L & Relatively rare locally & Very little known & - \\
\hline Maianthemum bifolium (L.) F. W. Schmidt & Probably doesn't occur any more & Not known & - \\
\hline Melampyrum nemorosum $\mathrm{L}$ & Probably doesn't occur any more & Not known & - \\
\hline Nymphoides peltata (S. G. Gmel.) Kuntze & Occurs on one lake only & Very little known & - \\
\hline Polygonatum multiflorum (L.) All & Rare in the forest & Not known & - \\
\hline Ranunculus trichophyllus Chaix & Common in marshes & Very little known & $\begin{array}{l}\text { A kind of ljutić (Ranuncu- } \\
\text { lus), paprat (insignificant) }\end{array}$ \\
\hline Rhamnus cathartica L & Not rare in the region & Very little known & Local name: kereće grožđe \\
\hline Salvinia natans (L.) All & Not rare in flooded wetlands & Very little known & Lokvanj in the Bosut \\
\hline Silene flos-cuculi (L.) Clairv & Sporadic in wet areas & Very little known & - \\
\hline Sparganium erectum $\mathrm{L}$ & Sporadic in wetlands & Not known & - \\
\hline Stratiotes aloides $\mathrm{L}$ & At only one marsh & Not known & - \\
\hline Vinca minor $\mathrm{L}$ & Rare in the forest & Little known & In gardens \\
\hline
\end{tabular}

Foraging varied greatly depending on the season. Pigs grazed on marsh and forest plants and anything that remained green in winter while foraging dominantly on Quercus robur acorns and/or earthworms. Pigs loved the young fresh herb, grass and shrub leaves (especially Agrostis stolonifera, Ranunculus ficaria, Crataegus spp.) sprouting in spring, and foraged on the remaining acorns. By mid-summer leaves hardened or dried: "the forest is empty, hungry". Pigs grazed in sunny places and on grasses and waterweeds of drying and waterlogged marshes. Svinjars recalled that in the past, pigs were driven to feed on the weeds and crop residues of stubble fields in this "empty" period. In August and September acorns start falling, and forest fruits (cherry plum in July, followed later by wild pear and apple) start ripening. Pigs foraged on acorns (loved more after rains) and on fallen tree leaves (mostly Acer campestre and Fraxinus angustifolia). Foraging during the autumn and winter season depended on the availability of acorns. In snowy winters, pigs foraged more on the 'roots' of marsh plants (e.g. chewing on Carex rhizomes) and, when in severe need, on certain wild fruits (Prunus spinosa, Crataegus spp.). If there were no acorns, they searched for earthworms and ate remaining fruits and green leaves. Pigs ate'roots' (but only of non-woody species) mostly in winter, and especially in forage-poor years.

Contradictory information on foraging was rare. Svinjars disagreed on altogether 8 species, but three were rare in the forest (Viola alba, Marsilea quadrifolia, Typha spp.); in four cases (Viola reichenbachiana, Oenanthe 
aquatica, Plantago major and Primula acaulis) one or two svinjars disagreed with the others whether it was foraged or not. Svinjars' reports contradicted our observations only for Erigeron annuus and Glechoma hederacea and for a further 5 species, but for the latter the difference was only whether the species were 'not eaten' or 'only nibbled' (see Table 2 for details).

Some plants were foraged only in a short time-window and/or in a given phenological state (e.g. young leaves of tree and shrub species mainly in the spring, Juncus 'roots' in snowy winters). Most plant species were foraged only for very short time periods during the observations (less than a minute even if available), except: acorns, marsh grasses (Agrostis, Glyceria), Carex rhizomes, Polygonum aviculare, Ranunculus ficaria, Crataegus spp. leaves, Lemna-Spirodela spp., Glechoma hederacea, Circaea lutetiana, and fallen leaves of Acer campestre and Fraxinus angustifolia.

Some species were reported as only eaten by pigs if nothing else was available (famine foods for pigs). For example, the fruits of Acer campestre, Rosa canina and Cornus sanguinea, and the 'roots' of Carex elata, Juncus effusus and Urtica dioica. Svinjars added: "They have to love them... if they are in need [food shortage]." Some plant species were reported as being eaten differently by or having a different impact on pigs (of the same breed), depending on whether they were kept at home in the village or in the forest (Chenopodium album, Urtica dioica).

Grasses and herbs growing in sunny places at forest edges, along lanes and roadsides were called "pitomina" (from the word tame and animal feed), as opposed to the lower quality grasses and herbs growing in the shade of the forest. Persicaria dubia (P. mite) was reported and observed as being mostly eaten in sunny places. Pigs grazed 'precisely', i.e. they were able to focus on the preferred species. For example, they grazed Rorippa amphibia from among Mentha aquatica, and Glyceria and Agrostis grasses from among Chaiturus (Leonurus) marrubiastrum.

Svinjars rarely drove pigs deliberately to forage on specific species and in specific places, and did so mostly in the past: Quercus robur and Q. cerris acorns, grassy village pastures in summer, beech mast (to mountains, but only in the past), waterweeds (lokvanj) in the rivers, and stubble fields. Driving and keeping pigs away from certain forages or sites was still practised: unharvested arable crops, reforestations (with acorns), areas designated for acorn collection, hunting areas, and to prevent damage to river dykes, railway and road verges.

Svinjars argued that "those pigs are the most 'beautiful' which can go wherever they want." "The 12-year-old sows know exactly where to look for what they want." "Pigs know the forest six times better than me, although
I also know each and every tree..." Svinjars were aware of individual and herd-level differences: "You know, some of my pigs eat mushrooms, others don't, they learn which mushrooms are edible from other herd members." We also observed that Ranunculus ficaria was eaten often by one herd and much less often by the neighbouring herd.

\section{Knowledge generation about plants and pig behaviour}

When asked about their knowledge of the forest, plants and pigs, and life in the forest, svinjars argued that " $I$ was born into this forest." "As if we were 'shot' into the forest." "Here everything is clear to me." The main source of knowledge was direct observation of pigs (see answers in Table 2). Svinjars were observant people. "Pigs mostly eat it [Crataegus spp. and Prunus spinosa fruits, Juncus roots] in winter if there is snow." "This plant [Lamium galeobdolon] doesn't grow in the forests I went to with my pigs." "I saw this plant [Myosotis scorpioides] in her mouth but did not actually see it being swallowed." "I have never seen pigs bother with žesta [Acer tataricum]." "I love watching birds and other animals." "I watched it [Dryopteris] for years, [I am sure] it has no flowers!"

On the other hand, svinjars lacked knowledge about certain plants. "I am used to seeing these plants, [but] I do not observe them carefully." "These [two plants: Carex remota and C. divulsa] are the same to me, but I know that they are not the same to you." Plants regarded as useless or not important were called "korov" (weed) or "paprat" (i.e. fern but meaning ca. weed/insignificant), and many Asteraceae species were called "kamilica" (chamomile) or "divlja [wild] kamilica" though svinjars knew that it was not the real chamomile.

Svinjars regularly but not often followed their free ranging pigs into the forest, even less often into marshes. "Pigs like freedom, like we do. They know where the best acorn is." However, they did keep an eye on how far pigs went, and whether pigs entered into forbidden areas (forests closed from grazing, road verges and arable fields). Over many decades, svinjars accumulated a large amount of experience about plants and pigs.

The interviewed svinjars had decades-long and personal experience with forest pigs. "Till it goes 'through your back', you don't know it." (i.e. effective learning needs personal experience). "You have to see them every day from their birth to know them well." And they do visit pigs almost every day, all year round, bringing food and checking on health and piglets. Svinjars spoke from experience, having lived through forage-rich and forage-poor years and seasons, and observed rare events (floods, severe winters) and long-term gradual changes of their environment. For example, the long-term impact of river regulation on the hydrology and species composition of marshes and forests, the impact of cattle grazing on the forests 
and marshes and the consequences of the abandonment of cattle and sheep grazing, the impact of pollution on waterweeds in the Bosut river, and the spread of new (invasive alien) species. Svinjars did not guess an answer to our questions, instead they said: "I don't know whether pigs eat it or not." "I don't want to say stupid things when I simply don't know this." Or simply closed the conversation by saying: "You know, everything is connected in the world." "Nature is a wonder both to us and to you...".

Some svinjars were eager to learn from parents, grandparents, other old villagers and from respected foresters. Svinjars regularly recalled stories elders had told them (Table 2, e.g. why Ajuga reptans is green in winter, the incredible endurance of Elytrigia and Cynodon rhizomes, masting in far-away mountains in the past). Other svinjars claimed: "I was never interested in what grandpa showed us." But all agreed: "Those old guys knew more [about pigs, forests and plants] than we do." Svinjars regularly visited their neighbour svinjars in the forest and shared information on pig movements (e.g. lost males), currently available forages, the impact of recent weather events (e.g. heat days on acorns), and changing forestry and veterinary regulations. Most local plant names documented in Table 2 were widely shared among svinjars.

All svinjars also had work experience as farmers, and most had also been employed as forest workers. In their childhood they played a lot in the forest, collected edible and medicinal plants, mushrooms, flowers, fodder for the pigs (acorn, Chenopodium, Amaranthus and Elytrigia from arable fields), and wood for firewood, huts, tools and sticks. They had therefore been familiar with many (probably most) plant species since early childhood. Svinjars remembered some practices from their childhood when they pastured pigs on weeds in stubble fields. They also acquired plant knowledge from foresters. They often recalled Dr. Josip Erdeši, former head of the Višnjićevo forestry office, who respected svinjars and supported pig grazing in the forests (Erdeši said to svinjars: "as long as the livestock is in the forest, it is beneficial to the forest, and when there is no more livestock in the forest, the forest will become ill"). TV and school were rarely mentioned as sources of plant knowledge (except in connection with the marketed wild green Allium ursinum). During the years of our research, svinjars became more interested in some plant species and the nuances of foraging behaviour. "[Last year] I told you that pigs don't eat this [Lysimachia nummularia] but now I can see they are eating it."

\section{Discussion}

\section{Knowledge of plants and foraging pigs}

Svinjars distinguished between at least 181 wild plant taxa in the studied forested floodplain, and had knowledge of 154 species foraged regularly or rarely, or avoided by pigs. This is the highest number of species documented for foraging domestic pigs in Europe (cf. [25, 26, 37]). The depth of ethnobotanical knowledge was comparable to other Central European traditional ecological knowledge-rich regions (e.g. Gyimes in Romania [91]; Hortobágy in Hungary [89], and also comparable to the length of lists of plant species foraged by wild boar [64, $69,70]$.

Svinjars saw and understood many forest and marsh plant species "through the mouth" of their pigs (loved, nibbled, avoided, toxic, medicinal, cf. [51]) but were also knowledgeable about the ecological needs (e.g. habitat requirements) and human uses (medicinal, tools, wild food etc.) of the species. Svinjars had especially rich knowledge on some plant species (and groups), for example on Quercus robur and its acorns, Ranunculus ficaria, marsh grasses, Carex spp. For these species, foraging behaviour was reported in a nuanced way.

The low number of interviewed informants (however knowledgeable) is an obvious limitation of our study (cf. [94]). We were able to reach the saturation of information only for the well and moderately known species. Some plants, despite being common in our study area and even eaten by pigs, were little known by svinjars. A possible reason for uncertainties in the knowledge of svinjars may be their lack of awareness of some 'insignificant' plant species (e.g. Circaea lutetiana, Veronica montana, Glechoma hederacea, Ranunculus trichophyllus, Teucrium scordium, Stachys palustris). Such 'ignorance' was also found in other ethnobotanical studies in the region [89, 91]. Furthermore, svinjars were cautious and tried to base their answers on their own observations. They all knew that we are botanists and have detailed knowledge of the local flora and already have some observational experience on pig foraging, so were careful with their answers. Some gaps in svinjars' knowledge may be due to a lack of knowledge (these plants were never known well in this area) or recent loss of knowledge (ancestors knew the species but it is not any more known) (cf. [95]).

Our own observational research also failed to produce a full picture of pig foraging. For many species we lacked visual observation data because (1) areas where these species grow were not utilized any more by pigs (stubble fields, old-fields, grassy pastures, road verges in arable land); (2) some species were rare in the forests or did not occur in the areas where the observations were done; and (3) some species are eaten only rarely and/or in a narrow seasonal window and/or under specific weather conditions (snow) or as a famine food, hence foraging was not observed.

Studies on pig foraging in open landscapes have found that herbaceous species are a staple food for pigs $[23,25,26]$. This was also the case in our research. The 
year-round main forages of pigs were similar to those of wild boar (grasses and herbs in spring, crops in summer, forest fruits and acorns in autumn, and acorns, grasses and roots in winter [64, 65] and references therein) except for crops. As we also observed in the case of pigs, wild boar prefer grasses over forbs $[65,96]$, but see the opposite for pigs in Von Flegler et al. [25].

The only available published comprehensive list of plant species foraged by free-ranging domestic pigs was compiled by Von Flegler et al. [25]. Their list shares many similarities with our list, although they studied grassland pastures and not forests (pigs love Cirsium arvense, Taraxacum officinale, eat regularly Agrostis stolonifera, Bidens frondosa, Iris pseudacorus, Stellaria media). Wild boars also forage on many wild herbaceous species, though usually there is no quantitative information available: Taraxacum officinale, Convolvulus arvensis, Moehringia trinervia, Stellaria media, Rumex acetosa, Pulmonaria officinalis, Cynodon dactylon, Symphytum officinale, Trifolium spp., Urtica spp. [64, 69, 70].

Historical-ethnographic sources on traditional pig keeping from the region list relatively few wild plant species eaten by pigs (see [32] and Öllerer et al. ined.), probably because ethnographers and historians were interested in the extensive land-use practices in general and focused especially on the social background and social organization, and on the use of agricultural tools and buildings for livestock. We can only presume that Central European ethnographers and local historians did not use the free-listing method as a way of elicitation, as only the most salient species (e.g. Quercus spp., Typha, Phragmites) were listed in the publications. None of the ethnographic-historical sources mentioned the regularly eaten (and loved) Amaranthus retroflexus, Polygonum aviculare, Chenopodium album, Convolvulus arvensis, Trifolium spp. and Taraxacum officinale as foraged. Studies on wild food plants may also list species eaten by (given to) pigs (e.g. [97]).

Acorns were a staple forage, and svinjars kept estimating the potential autumn yield from April onwards. This was a widespread practice in the past throughout Europe [20]. Only fallen acorns were eaten in our study area, svinjars did not shake or beat down acorns with sticks in August-September, a practice known in medieval times [14] and still applied by local svinjars as recently as $30-40$ years ago.

Pigs in the Bosut forest loved fleshy forest fruits. Wild boars also often feed on almost all fruits available in their territory (2-3\% in volume [64]). On the Drava floodplain, Tucak [70] documented foraging by wild boar on Prunus domestica, Morus alba, Corylus avellana, Rubus sp., a similar list to ours. Most cultivated fruits were given traditionally to Iberian pigs as supplementary fodder [63]. Fruit consumption is also important ecologically as it contributes to the dispersal of these species in the forested landscape [98].

We found 20 species whose 'roots' were foraged by pigs. Pigs studied in Germany foraged on the roots of many herbaceous species (e.g. various grasses, Cirsium arvense, Taraxacum officinale and Urtica dioica [25], also observed by Stolba and Wood-Gush [23]), while dehesa pigs eat much fewer roots $(<1 \%$ in volume [28]). Ethnographic sources also often mention digging for 'roots' of wetland plants (mostly but not exclusively in winter and early spring) $[12,15,99,100]$. Roots of marsh plants can also compose the bulk of food for wild boars living in wetlands, although it remains a secondchoice food source [101].

Literature sources (both historical, e.g. [99, 102], and recent, e.g. [23] mention that pigs forage on the roots of woody forest species, but the species are rarely documented (for wild boar, e.g. [69, 70]). We tried to document this behaviour, but not once did we observe pigs foraging on the roots of woody species, and svinjars were also convinced that it did not take place ("domestic pigs do not need these roots, they never eat woody roots, they get corn from us"). Roots were only broken and torn, or if pigs did take them into their mouths, they ultimately discarded them. In the Drava floodplain, wild boars consumed, in the four seasons from spring to winter, $20 \%, 9 \%, 15 \%$ and $48 \%$ roots, respectively (in volume [70], but woody and non-woody species were not distinguished), including roots of Quercus robur, Populus spp., Salix spp., Corylus avellana, Acer spp., Robinia pseudoacacia, as well as of non-woody species such as Symphytum officinale (most commonly in winter and spring), Taraxacum officinale, Trifolium sp., Pteridium aquilinum and grasses [70]. We did not observe pigs foraging on grass roots in our study area at any time.

There is almost no data on browsing by wild boar and little by pigs. Svinjars argued that pigs prefer leaves over twigs, the opposite of red deer, and we also observed grazing much more often than browsing. Wild boars also rarely browse $[65,103,104]$, max. up to $5 \%$ in volume [105]. Browsing by pigs is rarely mentioned in recent (Von Flegler et al. 2005, 2.6\%) or historical sources (on Fagus, Carpinus, Fraxinus, Ulmus, Acer and Salix caprea [106], and Crataegus sp. [107].

In spite of domestication, the behaviour of domestic pigs greatly resembled that of wild boar (cf. [23]). Consequently, the direct visual investigation of these easily observable domestic pigs could provide a reasonable basis for formulating research hypotheses for studies on the foraging behaviour of wild boar or for a better 
understanding of causes shaping wild boar grazing and rooting patterns (cf. [108]).

\section{Knowledge generation about pigs and plants}

Svinjars were born and embedded into this lifestyle, were knowledgeable about plants and pig foraging, and emphasized the importance of personal, long-term, everyday experience with the animals and the forest. This understanding of how adequate knowledge of animal keeping and pastures is generated is universal among herder and pastoralist communities $[89,109,110]$.

Though svinjars spent a lot of time with their pigs in the forest, they usually did not follow them on their foraging trips. This may be one of the reasons why some species and their consumption remained outside the knowledge of the svinjars. Inga [111] found that the knowledge of Sami reindeer herders about summer forages was significantly lower than about winter (e.g. lichen) forage, because the interviewed Sami herders usually did not follow their reindeers during summer months. By contrast, many European sheep and cattle herders still closely follow their herds during the whole grazing season, develop a deep understanding of foraging preferences and behaviour, and even use this knowledge to moderate appetite and increase forage intake $[5,52]$.

We found similar patterns and ways of ecological knowledge generation and knowledge transmission to those documented in other traditional indigenous and local communities [112-114]: vertical learning (within genealogical lines), oblique knowledge transmission (between genealogical lines-e.g. older colleagues) and horizontal transmission (between members of the same generation). The dominance of shared folk plant names was an indication of the operation of knowledge transmission mechanisms and indicated frequent contact and interaction between svinjars [115]. Personal experience with nature completed knowledge transmission, while non-local sources, information gained from school or media (books, newspapers, TV, internet), were rarely mentioned, as information on pig foraging is probably rare in these sources (cf. [89]). Based on our limited number of data, personal observation seemed to be more important with regard to forage-related traditional knowledge than vertical learning from older community members (cf. [116]).

Our research definitely had an impact on knowledge generation: svinjars became more observant on some species. This is also a general phenomenon, as herders like to learn from people whom they consider, in their own judgement, to have reliable and relevant knowledge [5].

Traditional knowledge on forages and foraging was eroding in the study area, while knowledge of particular species is becoming less in-depth (cf. [95]). Similarly to other local knowledge holders worldwide, the interviewed svinjars argued that they knew less about the plants than their fathers and grandfathers did. Svinjars also emphasized the diminished dependence on pigs and local natural resources, which led to less effective knowledge generation (they accompany their pigs less often than in the past). Formal education, connections to the market economy and changing lifestyles may reduce not only the amount of local ecological knowledge but also the willingness of younger generations to continue this lifestyle (cf. [117]). The almost complete absence of the next generation of svinjars has practically ended knowledge transmission. The decreasing number of practising svinjars may also have caused a decline in the diversity of experiences. The ageing and dwindling community of svinjars is leading to the disappearance of the informal socio-cultural institutions of knowledge transmission and eliminating opportunities for imitation and improvisation as important mechanisms in knowledge acquisition $[114,118,119]$.

Svinjars were eager to teach us their knowledge and hoped that science could help archive their knowledge, and even improve knowledge transmission by raising interest among the younger generation to learn more about traditional pig keeping [a new local association of pig keepers was recently formed to preserve traditional farming practices (svinjars' pers. comm.)]. However, economic drivers, the worsening of the local and the national regulatory environment and the spread of modern lifestyles still threaten the continuation of this traditional forest-marsh pig keeping practice [31, 32].

\section{Future potential of this almost lost traditional practice}

The historical practice of extensive pig grazing is regularly advocated for use in land management, for example, in forestry $[34,102,120,121]$, nature conservation management [6, 21, 40,41], and organic/environmentally friendly farming [34, 38, 39].

The possibility of using pig grazing and rooting in nature conservation management is, however, hardly understood [122], and may also be misunderstood and undervalued [41]. Evidence shows that extensive pig keeping is an efficient way of managing some mud specialist species and of restoring formerly grazed marshes $[6,40]$. For example, several red-listed marsh plant species (Marsilea quadrifolia, Ludwigia palustris, Elatine spp., Hottonia plaustrisi Lindernia procumbens etc. [6]) benefit from pig grazing, as do some birds (waders, ducks and geese [41]). Pigs were also suggested for managing wood-pastures and open forests, based on their interwoven history [14] and on the experience of the ongoing practice in the dehesas (e.g. [27]). 
The carefully controlled application of livestock grazing in certain forest management situations is recommended by Öllerer et al. [46], which is in line with the knowledge and view of some forestry experts (e.g. [84, 123-125]). Data on the forestry use of pig grazing are, however, also scarce. Historical data indicate that pigs were used before the planting of tree seedlings to eat up wormy, unhealthy acorns and to loosen up the soil, mixing it with leaf litter in order to achieve better conditions for the germination of healthy acorns that fell subsequently [85], but also to provide protection against Rubus and weed invasion and against pests (insects, small rodents) [120, 121, 124-126]. However, more research is needed to understand the potential benefits of pig grazing in present-day forestry systems, as habitats (their hydrology, abundance of invasive species) may have changed considerably since the nineteenth century [127]. The use of free-ranging pigs in modern agroforestry systems (e.g. with fast growing tree crops $[38,39]$ is a novel practice of raising pigs in an environmentally friendly way. The use of pigs to open up dense encroached secondary forests to more intensive use and to loosen and clear their soil for agriculture is being tested on US and UK farms [128, 129].

Knowing the often detrimental impact of wild boars on semi-natural habitats [130] one may ask: are domestic pigs better than wild boars? We cannot answer this question for certain at present (there are no comparative studies in which spatial and temporal constraints etc. are controlled for), but we can be sure that domestic pigs seem to forage somewhat differently, while their impact can be managed more easily in space and time (to protect sensitive semi-natural habitats and crop fields). Historical data show that domestic pigs were not listed among the livestock types harmful for forests and the pig was the last livestock type excluded from the forests in the region [131].

We made our study in a high conservation value floodplain area that desperately needs an improved conservation management system. Floodplains are dynamic systems, where extreme events (especially unpredictable major floods) challenge conservation and the utilization of natural resources [29]. Innovations and creativity are needed for sustainable management and conservation. The studies of Kiš et al. [31, 32] show that extensive pig grazing has a place and role in this, especially with regard to maintaining open habitats and increasing water infiltration. Local pig keeping methods develop in order to adapt to market changes and new forestry and veterinary regulations, while still preserving many ancient elements. The adaptive capacity of the system is, however, limited, and needs strengthening.

We do not know what knowledge humanity will need in the coming decades and centuries in order to develop and survive. Scientists warn that ancient knowledge needs recognition and support at multiple levels in order to continue adapting [2,3]. Consequently, national and local governments, veterinarians, forestry companies and nature conservation institutions all have a share of responsibility in maintaining this special pig keeping practice for the future.

\section{Conclusions and outlook}

Traditional pig keepers (svinjars) in Serbia developed their deep ecological knowledge of plants and foraging behaviour of pigs by maintaining a close relationship with the forest, the pigs, plants and wild animals, and the knowledge of their ancestors. We started to document this huge body of knowledge, which is vanishing rapidly because of internal (e.g. livelihood changes) and external (e.g. markets, regulations) drivers.

A much deeper scientific understanding is needed of this traditional pig grazing practice to efficiently harness its potential for conservation management in protected areas and for organic farming (and forestry), and to understand its past impacts on the ecology of European deciduous forests. Knowledge co-production with further scientific disciplines and professions (e.g. ethnozoology, animal behaviour science, ecology, veterinary and food science) is needed to cover the wide spectrum of svinjars' knowledge. Svinjars with their pigs convert inedible (i.e. not consumed by humans nowadays) biomass, such as forest and marsh grasses and herbs, acorns, roots and earthworms, into high quality meat, using little modern technology. This knowledge is an invaluable intangible cultural heritage of Serbia.

Only a few svinjars remain in the Bosut floodplain, and hardly any of them is under the age of 60 . If external drivers are not managed properly, this practice may disappear very soon. Decision makers, in particular forestry, nature conservation, hydroengineering and veterinary experts and officials, need to recognize svinjars' knowledge and practices, support ongoing and future development and adaptation of this traditional practice, and support bottom-up initiatives to develop and promote local products and tourism. We hope that our study will encourage others to delve deeper into the knowledge and methods of traditional pig keeping in forests and marshes, and help the survival of this ancient practice.

\footnotetext{
Acknowledgements

We gratefully acknowledge all the pig keepers (svinjars) who patiently and generously shared their knowledge with us (Milutin Ajvazović, Borislav Runjanin, Lazar (Joza) Milanović, Vlada Mandušić, Jovica Stojaković, Zdravko Purić, Živan Vukić), the Morović and Višnjićevo forest offices of the Public Company Vojvodinasume and the Institute of Nature Conservation of Vojvodina Province for their support, and Steve Kane for English editing.
} 


\section{Authors' contributions}

ZM, AK, KS planned the study, ZM, KS, AK, LD, DB collected the field data and conducted the interviews, JM, KS, ZM transcribed the interviews, MB, KÖ, AK, KS, LD helped the study with historical data, RP contributed with local flora knowledge, LD, MB led and MĐ, VU assisted the botanical fieldwork, KK helped with wild boar literature. All authors read and approved the final manuscript.

\section{Funding}

The study was predominantly financed through the project NKFI K 119478 (ZM, LD, MB, KS, AK), KÖ was supported through the MTA Premium Postdoctoral Research Program of the Hungarian Academy of Sciences [PPD20197/2019] and from the Romanian Academy [RO1567-IBB03/2020]. DB and VU were supported by the Momentum Program of the Hungarian Academy of Sciences [MTA Lendület_2020-56].

\section{Availability of data and materials}

Databases used and cited are available upon request at the Institute of Ecology and Botany, Centre for Ecological Research, Vácrátót, Hungary.

\section{Declarations}

\section{Ethics approval and consent to participate}

The methods of obtaining data during fieldwork followed guidelines set by the International Society of Ethnobiology Code of Ethics and the GDPR of the European Union, and adhered to local traditions for such research. Free prior informed consent was obtained from all study participants. No ethical committee permits were required.

\section{Consent for publication}

Not applicable.

\section{Competing interests}

The authors declare that they have no competing interests.

\section{Author details}

${ }^{1}$ Centre for Ecological Research, Institute of Ecology and Botany, Vácrátót 2163, Hungary. ${ }^{2}$ Institute for Nature Conservation of Vojvodina Province, Novi Sad 21101, Serbia. ${ }^{3}$ MTA-DE 'Lendület'Evolutionary Phylogenomics Research Group, Hungarian Academy of Sciences, Debrecen 4032, Hungary. ${ }^{4}$ Institute of Biology Bucharest, Romanian Academy, Bucharest 060031, Romania. Institute for Wildlife Management and Nature Conservation, Hungarian University of Agriculture and Life Sciences, Gödöllő 2100, Hungary. ${ }^{6}$ Research Centre for the Humanities, Institute of Ethnology, Budapest 1097, Hungary.

Received: 22 May 2021 Accepted: 18 September 2021

Published online: 09 October 2021

\section{References}

1. Johnsen Kl, Niamir-Fuller M, Bensada A, Waters-Bayer A. A case of benign neglect: Knowledge gaps about sustainability in pastoralism and rangelands. United Nations Environment Programme and GRIDArendal, Nairobi and Arendal. 2019. www.grida.no. 78 pp.

2. IPBES.Summary for policymakers of the global assessment report on biodiversity and ecosystem services. In: Díaz $S$ et al, editors. IPBES Secretariat. Bonn; 2019. https://ipbes.net/sites/default/files/2020-02/ipbes_ global_assessment_report_summary_for_policymakers_en.pdf.

3. Fernández-Llamazares Á, Lepofsky D, Armstrong CG, Brondizio ES, Gavin MC, Lertzman K, et al. Scientists' warning to humanity on threats to Indigenous and local knowledge systems. J Ethnobiol. 2021;41:144-69.

4. Oteros-Rozas E, Ontillera-Sánchez R, Sanosa P, Gómez-Baggethun E, Reyes-García V, González JA. Traditional ecological knowledge among transhumant pastoralists in Mediterranean Spain. Ecol Soc. 2013. https://doi.org/10.5751/ES-05597-180333.

5. Molnár Z, Kelemen A, Kun R, Máté J, Sáfián L, Biró M, et al. Knowledge co-production with traditional herders on cattle grazing behaviour for better management of species-rich grasslands. J Appl Ecol. 2020;57:1677-87. https://doi.org/10.1111/1365-2664.13664.
6. Biró M, Molnár Z, Öllerer K, Lengyel A, Ulicsni V, Szabados K, et al. Conservation and herding co-benefit from traditional extensive wetland grazing. Agr Ecosyst Environ. 2020;300:106983. https://doi.org/10. 1016/j.agee.2020.106983.

7. Hill BT, Beinlich B, Köstermeyer H, Dieterich M, Neugebauer K. The pig grazing project: prospects of a novel management tool. In: Dieterich $M$, Van Der Straaten J, editors. Cultural landscapes and land use. Springer: Dordrecht; 2004. p. 193-208. https://doi.org/10.1007/1-4020-2105-4_ 12.

8. Poschlod P. Geschichte der kulturlandschaft. Stuttgart: Ulmer Verlag; 2015.

9. Hamilton J, Hedges RE, Robinson M. Rooting for pigfruit: pig feeding in neolithic and iron age britain compared. Antiquity. 2009;83(322):998. https://doi.org/10.1017/S0003598X00099300.

10. Ten Cate CL. Wan god mast gift... Bilder aus der Geschichte der Schweinezucht im Walde. Wageningen: Centre for Agriculture Publishing and Documentation; 1972.

11. Plochmann R. Mensch und Wald. In: Stern H, editor. Rettet den Wald München. München: Kindler Verlag; 1979. p. 157-97.

12. Szabadfalvi J. Az extenzív sertéstenyésztés emlékei Magyarországon. A Debreceni Déri Múzeum Évkönyve 1969-1970, Debrecen; 1971.

13. Belényesy M. Fejezetek a középkori anyagi kultúra történetéből I-II. Documentatio Ethnographica 29. Budapest: L'Harmattan, MTA BTK Néprajztudományi Intézete; 2012.

14. Jørgensen D. Pigs and pollards: medieval insights for UK wood pasture restoration. Sustainability. 2013;5(2):387-99.

15. Szabadfalvi J. A sertés Magyarországon. Ethnica Alapítvány, Debrecen; 1992.

16. Prica R. (Прица Р.). Привреда Сремске границе у Терзић, in Срем у прошлости (Economy of the border region Serem in Terzic in the past). Сремске Новине, Сремска Митровица ст; 1986. pp. 68-70.

17. Redep M, Lugoj M. Stočarstvo varaždinske županije, Univerzitet u Zagrebu, Varaždin, Zbornik radova. 1986;85/86(9-10):303-21.

18. Domaćinović V. Predajno gospodarstvo u Baranji. Stud Ethnol Croat. 1992:4:23-47.

19. Halpern J. The ecological transformation of a resettled area, pig herders to settled farmers in Central Serbia (Sumadija, Yugoslavia) during the 19th and 20th centuries. In: Bartosiewicz L, Greenfield HJ, editors. Transhumant pastoralism in Southern Europe. Recent perspectives from archaeology, history and ethnology. Budapest: Archaeolingua; 1999. p. 79-98.

20. Szabó P. Rethinking pannage: historical interactions between oak and swine. In: Rotherham ID, editor. Trees, forested landscapes and grazing animals. Routledge: London; 2013. p. 68-78.

21. Neugebauer KR, Beinlich B, Poschlod P, editors. Schweine in der Landschaftspflege-Geschichte, Ökologie, Praxis. NNA-Berichte, 18, 2. Alfred Toepfer Akademie für Naturschutz (NNA), Schneverdingen; 2005.

22. Varga A, Molnár Z, Biró M, Demeter L, Gellény K, Miókovics E, et al. Changing year-round habitat use of extensively grazing cattle, sheep and pigs in East-Central Europe between 1940 and 2014: consequences for conservation and policy. Agric Ecosyst Environ. 2016;234:142-53. https://doi.org/10.1016/j.agee.2016.05.018.

23. Stolba A, Wood-Gush DGM. The behaviour of pigs in a semi-natural environment. Anim Sci. 1989;48(2):419-25.

24. Poschlod P, Schneider-Jacoby M, Köstermeyer H, Hill BT, Beinlich B. Does large-scale, multi-species pasturing maintain high biodiversity with rare and endangered species? - The Sava floodplain case study. In: Redecker B, Finck P, Härdtle W, Riecken U, Schröder E, editors. Pasture landscapes and nature conservation. Berlin, Heidelberg: Springer; 2002. p. 367-78. https://doi.org/10.1007/978-3-642-55953-2_28.

25. von Flegler J, Beinlich B, Van Rhemen K, Köstermeyer H, Hill BT, Beck LA. Untersuchungen zur Raum-Zeit-Nutzung Tagesaktivität und Nahrungswahl extensiv gehaltener Weideschweine. In: Neugebauer KR, Beinlich B, Poschlod P, editors. Schweine in der Landschaftspflege-Geschichte Ökologie. Schneverdingen: Praxis—NNA-Berichte; 2005. p. 58-67.

26. Rodríguez-Estévez V, García A, Peña F, Gómez AG. Foraging of Iberian fattening pigs grazing natural pasture in the dehesa. Livest Sci. 2009;120(1-2):135-43. https://doi.org/10.1016/j.livsci.2008.05.006.

27. Rodríguez-Estévez V, Sánchez-Rodríguez M, Arce C, García AR, Perea JM, Gómez-Castro AG. Consumption of acorns by finishing Iberian pigs and their function in the conservation of the dehesa agroecosystem. In: 
Kaonga $\mathrm{M}$, editor. Agroforestry for biodiversity and ecosystem services. Science and practice. London: InTechOpen; 2012. p. 1-22.

28. Rivero MJ, Rodríguez-Estévez V, Pietrosemoli S, Carballo C, Cooke AS, Kongsted AG. Forage consumption and its effects on the performance of growing swine-discussed in relation to European wild boar (Sus scrofa L.) in semi-extensive systems: a review. Animals. 2019;9(7):457. https://doi.org/10.3390/ani9070457.

29. Gugić G. Managing sustainability in conditions of change and unpredictability. The living landscape and floodplain ecosystem of the Central Sava river basin. Krapje: Lonjsko Polje Nature Park Public Service; 2009.

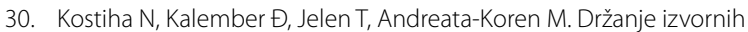
i zaštićenih pasmina domaćih životi nja i njihov utjecaj na biološku raznolikost u parku prirode Lonjsko polje. In: Proceedings and abstracs of 6th international scientific/professional conference: agriculture in nature and enviroment protection, Vukovar; 2012. p. 67-78 https:// www.bib.irb.hr/87119.

31. Kiš A, Stojnić N, Sabadoš K, Đapić M, Bošnjak T, Molnar Ž, et al. Advocating ESAV in bosut forest area: integrating biodiversity and ecosystem services in natural resource management. Case study for GIZ open regional fund for south-east Europe—biodiversity (ORF BD) sub-project "ecosystem services and valuation (ESAV) in future course of action in south-east Europe region". prepared by Institute for Nature Conservation of Vojvodina Province, Novi Sad; 2018

32. Kiš A, Stojnić N, Pavkov S, Sabadoš K, Bošnjak T, Puzović S, et al. Case Study Bosut Forests piloting of Regional (Western Balkans) Guidelines on Ecosystem Services Assessment and Valuation. Institute for Nature Conservation of Vojvodina Province, Novi Sad; 2020.

33. Biró M, Molnár Z, Babai D, Dénes $A$, Fehér A, Barta S, et al. Reviewing historical traditional knowledge for innovative conservation management: a re-evaluation of wetland grazing. Sci Total Environ. 2019;666:1114-25. https://doi.org/10.1016/j.scitotenv.2019.02.292.

34. Brownlow MJC, Dorward PT, Carruthers SP. Integrating natural woodland with pig production in the United Kingdom: an investigation of potential performance and interactions. Agroforest Syst. 2005;64(3):251-63. https://doi.org/10.1007/s10457-004-0250-6.

35. Karolyi D, Luković Z, Salajpal K. Crna slavonska svinja. Meso Prvi Hrvatski Časopis O Mesu. 2010;12(4):222-30.

36. Rey Al, Daza A, López-Carrasco C, López-Bote CJ. Feeding Iberian pigs with acorns and grass in either free-range or confinement affects the carcass characteristics and fatty acids and tocopherols accumulation in Longissimus dorsi muscle and backfat. Meat Sci. 2006;73(1):66-74. https://doi.org/10.1016/j.meatsci.2005.10.018.

37. Rodríguez-Estévez V, Sánchez-Rodríguez M, García AR, Gómez-Castro AG. Average daily weight gain of Iberian fattening pigs when grazing natural resources. Livest Sci. 2011;137(1-3):292-5. https://doi.org/10. 1016/j.livsci.2010.11.015

38. Kongsted AG. Agroforestry for organic poultry and pig production in Denmark. Aarhus University, Aarhus; 2014. http://www.agforward.eu/ index.php/en/free-range-pigs-integratedwith-energy-crops.html.

39. Bondesan V. Agroforestry for free-range pig production in Veneto Region (Italy): research and development protocol. Veneto: Veneto Agricoltura; 2015

40. Beinlich B, Poschlod P. Low intensity pig pastures as an alternative approach to habitat management. In: Redecker B, Härdtle W, Finck P, Riecken U, Schröder E, editors. Pasture landscapes and nature conservation. Berlin, Heidelberg: Springer; 2002. p. 219-26.

41. Ecsedi Z, Zalai T, Oláh J, editors. Ecology and management of grazing soda marshes in the Hortobágy. Balmazújváros: Hortobágy Természetvédelmi Egyesület; 2020.

42. Biró M, Bölöni J, Molnár Z. Use of long-term data to evaluate loss and endangerment status of Natura 2000 habitats and effects of protected areas. Conserv Biol. 2018;32:660-71. https://doi.org/10.1111/cobi.13038.

43. Varga A, Demeter L, Ulicsni V, Öllerer K, Biro M, Babai D, et al. Prohibited, but still present: local and traditional knowledge about the practice and impact of forest grazing by domestic livestock in Hungary. J Ethnobiol Ethnomed. 2020;16(1):1-12. https://doi.org/10.1186/ s13002-020-00397-x.

44. Schindler S, O'Neill FH, Biró M, Damm C, Gasso V, Kanka R, et al. Multifunctional floodplain management and biodiversity effects: a knowledge synthesis for six European countries. Biodivers Conserv. 2016;25:1349-82. https://doi.org/10.1007/s10531-016-1129-3.

45. Demeter L. Biodiversity and ecosystem services of hardwood floodplain forests: Past, present and future from the perspective of local communities in West Ukraine. In: Roué M, Molnár Z, editors. Knowing our land and resources: indigenous and local knowledge of biodiversity and ecosystem services in Europe \& Central Asia. Knowledges of nature 9. Paris: UNESCO; 2017. p. 6-19.

46. Öllerer K, Varga A, Kirby K, Demeter L, Biró M, Bölöni J, et al. Beyond the obvious impact of domestic livestock grazing on temperate forest vegetation-a global review. Biol Conserv. 2019;237:209-19. https:// doi.org/10.1016/j.biocon.2019.07.007.

47. Hunn E. Ethnobiology in four phases. J Ethnobiol. 2007;27(1):1-10. https://doi.org/10.2993/0278-0771(2007)27[1:EIFP]2.0.CO;2.

48. Molnár Z, Babai D. Inviting ecologists to delve deeper into traditional knowledge. Trends Ecol Evol. 2021;36:679-90. https://doi.org/10.1016/j. tree.2021.04.006.

49. Pieroni A, Price L. Eating and healing: traditional food as medicine. Boca Raton: CRC Press; 2006.

50. Łuczaj Ł, Szymański WM. Wild vascular plants gathered for consumption in the Polish countryside: a review. J Ethnobiol Ethnomed. 2007;3:17. https://doi.org/10.1186/1746-4269-3-17.

51. Molnár Z. "I see the grass through the mouths of my animals" - folk indicators of pasture plants used by traditional steppe herders. J Ethnobiol. 2017;37(3):522-41. https://doi.org/10.2993/0278-0771-37.3.522.

52. Meuret M, Provenza FD. When art and science meet: integrating knowledge of French herders with science of foraging behavior. Rangeland Ecol Manag. 2015;68(1):1-17. https://doi.org/10.1016/j.rama.2014.12. 007.

53. Tälle M, Deák B, Poschlod P, Valkó O, Westerberg L, Millberg P. Grazing vs. mowing: a meta-analysis of biodiversity benefits for grassland management. Agric Ecosyst Environ. 2016;222:200-12. https://doi.org/10.1016/j. agee.2016.02.008

54. Kovácsné Koncz N, Béri B, Deák B, Kelemen A, Tóth K, Kiss R, et al. Meat production and maintaining biodiversity: grazing by traditional breeds and crossbred beef cattle in marshes and grasslands. Appl Veg Sci. 2020;23(2):139-48. https://doi.org/10.1111/avsc.12475.

55. Roturier S, Roué M. Of forest, snow and lichen: sámi reindeer herders' knowledge of winter pastures in northern Sweden. For Ecol Manag. 2009;258:960-7. https://doi.org/10.1016/j.foreco.2009.07.045.

56. Berkes F, Colding J, Folke C. Rediscovery of traditional ecological knowledge as adaptive management. Ecol Appl. 2000;10(5):1251-62. https:// doi.org/10.2307/2641280

57. ISE International Society of Ethnobiology. International Society of Ethnobiology Code of Ethics (with 2008 additions). International Society of Ethnobiology, Vermont; 2006. http://ethnobiology.net/code-of-ethics/.

58. Reid A, Teamey K, Dillon J. Traditional ecological knowledge for learning with sustainability in mind. Trumpeter. 2002;18(1):113-36.

59. Middleton BA. Broken connections of wetland cultural knowledge. Ecosyst Health Sust. 2016;2(7):e01223. https://doi.org/10.1002/ehs2. 1223.

60. Molnár Z, Kis J, Vadász C, Papp L, Sándor I, Béres S, et al. Common and conflicting objectives and practices of herders and nature conservation managers: the need for the conservation herder. Ecos Health Sustain. 2016;2(4):e01215. https://doi.org/10.1002/ehs2.1215.

61. Babai D, Tóth A, Szentirmai I, Biró M, Máté A, Demeter L, et al. Do conservation and agri-environmental regulations effectively support traditional small-scale farming in East-Central European cultural landscapes? Biodivers Conserv. 2015;24:3305-27. https://doi.org/10.1007/ s10531-015-0971-Z

62. Molnár Z, Berkes F. Role of traditional ecological knowledge in linking cultural and natural capital in cultural landscapes. In: Paracchini ML, Zingari P, editors. Reconnecting natural and cultural capital—contributions from science and policy. Brussels: Office of Publications of the European Union; 2018. p. 183-94.

63. Rodríguez-Estévez V, López Tirado J, Sanz Fernández S, Reyes Palomo C, Díaz GC. Catálogo de plantas usadas tradicionalmente para alimentar a los cerdos. Córdoba: Universidad de Córdoba; 2020.

64. Schley L, Roper TJ. Diet of wild boar Sus scrofa in Western Europe, with particular reference to consumption of agricultural crops. Mammal Rev. 2003;33(1):43-56. https://doi.org/10.1046/j.1365-2907.2003.00010.x. 
65. Ballari SA, Barrios-García MN. A review of wild boar Sus scrofa diet and factors affecting food selection in native and introduced ranges. Mamm Rev. 2014;44(2):124-34. https://doi.org/10.1111/mam.12015.

66. Lombardini M, Meriggi A, Fozzi A. Factors influencing wild boar damage to agricultural crops in Sardinia (Italy). Curr Zool. 2017;63(5):507-14. https://doi.org/10.1093/cz/zow099.

67. Katona K, Heltai M. A vaddisznó táplálék-összetételének és táplálkozási sajátságainak szakirodalmi áttekintése. Tájökol Lapok. 2018;16(1):65-74.

68. Rutten A, Casaer J, Strubbe D, Leirs H. Agricultural and landscape factors related to increasing wild boar agricultural damage in a highly anthropogenic landscape. Wildl Biol. 2020;1:1-11.

69. Genov P. Food composition of wild boar in north-eastern and Western Poland. Acta Theriol. 1981;26:185-205. https://doi.org/10.4098/AT.arch. 81-16.

70. Tucak Z. Ergebnisse von 155 Mageninhaltsuntersuchungen von Schwarzwild (Sus scrofa L.) im ungegatterten Teil des Waldjagdrevieres Belje in Baranja. Z Jagdwiss. 1996;42:165-72.

71. Meynhardt H. Schwarzwild-report. Leipzig: Neumann Verlag; 1986. p. 218.

72. Noack A. Unter wildschweinen: meine jahre als frischlingsmutter im schwarzwildrevier. Ulm: Ulmer Eugen Verlag; 2018.

73. Erdtmann D, Keuling O. Behavioural patterns of free roaming wild boar in a spatiotemporal context. PeerJ. 2020;8: e10409. https://doi.org/10. 7717/peerj.10409.

74. Kraljić B. Veličina šumske paše u FNRJ, Годишен зборник на земјоделско-шумарскиот факултет на универзитетот СкопјеШумарство 1960;13:179-206.

75. Zingstra H, Kiš A, Ribarić A, Baković, D, Ilijaš I, Jeremić J, Galamboš L, Szabados K, Vukelić M, Predić T. Protection of biodiversity of the sava river basin floodplains: the relevance of farming and farmland for maintaining the landscape and biodiversity of the Sava floodplains. Land Use Working Group, Final Report of Task C of the EU LIFE TCY 06/ INT/246 Project. Wageningern University, Wageningen; 2010. p. 80.

76. Metlaš J. Slavonske stare hrastove šume (eksploatacija i kretanje cena u prošlosti). In: Pola stoleća šumarstva 1876-1926., Zagreb; 1926. pp. 424-438.

77. Erdődi A. A bródi határezred erdőségeinek leirása 1-3. Erdészeti Lapok. 1866;8:352-8.

78. Bobinac M. Savremeni pristup obnovi šuma tvrdih lišćara na području Ravnog Srema. In:Tomović Z, editor. 250 godina šumarstva Ravnog Srema, vol. 250. Petrovaradin: JP Vojvodinašume, ŠG Sremska Mitrovica; 2008. p. 127-36.

79. Tomović Z, editor. Monografija 250 godina šumarstva Ravnog Srema. Petrovaradin: JP Vojvodinašume; 2008. p. 376.

80. Vlatković S. Šume Ravnog Srema, opšte karakteristike i šumovitost područja. In: Tomović Z, editor. Monografija 250 godina šumarstva Ravnog Srema. Petrovaradin: Vojvodinašume; 2008. p. 7-18.

81. Cestarić D, Škvorc Ž, Franjić J, Sever K, Krstonošić D. Forest plant community changes in the Spačva lowland area (E Croatia). Plant Biosyst. 2017;151:584-97. https://doi.org/10.1080/11263504.2016.1179699.

82. Rauš D, Šegulja N, Topić J. Vegetacija bara i močvara u šumama jugozapadnog Srijema. Matica Srpska, Zbornik za prirodne nauke. 1980:58:17-51.

83. Perić R. Florističke odlike. In: Kiš A, editor. Park prirode "Bosutske šume" predlog za stavljanje pod zaštitu kao zaštićeno područje II kategorije, studija zaštite, (pp. 52-63, Appendix I, 1.). Novi Sad: Pokrajinski zavod za zaštitu prirode; 2016.

84. Euro+Med (2006+): Euro+Med Plant Base-the information resource for Euro-Mediterranean plant diversity. http://ww2.bgbm.org/EuroP lusMed/. Accessed 05 Mar 2021.

85. Kozarac J. To the question of oak forest regeneration in Sava River region (in Serbian/in Hungarian). Šumarski List, 1869;6:242-249/ Erdészeti Lapok. 1886;25:370-81.

86. Máté G. Vízkezelés és erdei sertéstartás a szerémségi Bázaközben. In: Kothencz K, editor. Víz, ember, örökség: Tanulmányok a 90 éve született Solymos Ede tiszteletére. Baja:Türr István Múzeum; 2017. p. 103-18.

87. http1: Natural Earth. https://www.naturalearthdata.com/downloads/. Accessed 04 Dec 2020.

88. http2: Corine Land Cover Map. 2018. https://land.copernicus.eu/paneuropean/corine-land-cover. Accessed 24 Mar 2021.
89. Molnár Z. Traditional ecological knowledge of herders on the flora and vegetation of the Hortobágy. Debrecen: Hortobágy Természetvédelmi Közalapítvány; 2012.

90. EU 2016/679 The General Data Protection Regulation, regulation (EU) 2016/679 of the European Parliament and of the Council, of 27 April 2016, Bruxelles. https://gdpr-info.eu/.

91. Babai D, Molnár Á, Molnár Z. Traditional ecological knowledge and land use in Gyimes (Eastern Carpathians). Budapest; Vácrátót: MTA Bölcsészettudományi Kutatóközpont Néprajztudományi Intézet; MTA Ökológiai Kutatóközpont Ökológiai és Botanikai Intézet, Budapest, Vácrátót; 2014. p. 123.

92. Dénes A, Papp N, Babai D, Czúcz B, Molnár Z. Wild plants used for food by Hungarian ethnic groups living in the Carpathian Basin. Acta Soc Bot Pol. 2012;81:381-96. https://doi.org/10.5586/asbp.2012.040.

93. Molnár Z. Hungarian folk plant names and their Latin equivalents. Vácrátót: Database, Centre for Ecological Research; 2015.

94. Herman-Mercer NM, Matkin E, Laituri MJ, Toohey RC, Massey M, Elder $\mathrm{K}$, et al. Changing times, changing stories: generational differences in climate change perspectives from four remote indigenous communities in Subarctic Alaska. Ecol Soc. 2016;21(3):28. https://doi.org/10.5751/ ES-08463-210328.

95. Biró É, Babai D, Bódis J, Molnár Z. Lack of knowledge or loss of knowledge? Traditional ecological knowledge of population dynamics of threatened plant species in East-Central Europe. J Nat Conserv. 2014;22(4):318-25. https://doi.org/10.1016/j.jnc.2014.02.006.

96. Durio P, Fogliato D, Perrone A, Tessarin N. The Autumn diet of the wild boar (Sus scrofa) in an alpine valley. Preliminary results. J Mount Ecol. 1995:3:180-3.

97. Kalle R, Sõukand R. The name to remember: Flexibility and contextuality of preliterate folk plant categorization from the 1830s, in Pernau, Livonia, historical region on the eastern coast of the Baltic Sea. J Ethnopharmacol. 2021;264:113254.

98. Mráz B, Katona K. Állati magterjesztés, kiemelten a vaddisznó (Sus scrofa) szerepe a növényzeti mintázatok kialakulásában-áttekintés. Gyepgazdálkodási Közlemények. 2014;1-2:39-47.

99. Andrásfalvy B. Duna mente népének ártéri gazdálkodása Tolna és Baranya megyében az ármentesítés befejezéséig. In: K Balog J, editor. Tanulmányok Tolna megye történetéből 7. Tolna Megyei Tanács Levéltára, Szekszárd; 1975.

100. Balassa I. A magyar sertéstartás történetének néhány kérdése. In: Pintér S, editor. A Magyar Mezőgazdasági Múzeum Közleményei 1988-1989, Budapest; 1990. pp. 235-52

101. Dardaillon M. Seasonal feeding habits of the wild boar in a Mediterranean wetland, the Camargue (Southern France). Acta Theriol. 1987;32(23):389-401.

102. Anonymous A. Makkoltatás hasznai (the benefits of pannaging). Gazdasági Lapok. 1859;37:585-6.

103. Miloš J, Michaela H, Tomáš K, Jaroslav Č. Creeping into a wild boar stomach to find traces of supplementary feeding. Wildl Res. 2016;43:590-8. https://doi.org/10.1071/WR16065.

104. Spitzer R, Felton A, Landman M, Singh NJ, Widemo F, Cromsigt JP. Fifty years of European ungulate dietary studies: a synthesis. Oikos. 2020;129(11):1668-80. https://doi.org/10.1111/oik.07435.

105. Merta D, Mocala P, Pomykacz M, Frackowiak W. Autumn-winter diet and fat reserves of wild boars (Sus scrofa) inhabiting forest and forest-farmland environment in south-western Poland. Folia Zool. 2014;63:95-102. https://doi.org/10.25225/fozo.v63.i2.a7.2014.

106. Benak V. Važnost mješovitih šuma. Šumarski List. 1887;7:282-93.

107. Hegyi L. A népi erdőkiélés történeti formái. Az Északkeleti-Bakony erdőgazdálkodása az utolsó kétszáz évben. Akadémiai Kiadó: Budapest; 1978. p. 318.

108. Hodgkinson SM, Polanco C, Aceiton L, Lopez IF. Pasture intake and grazing behaviour of growing European wild boar (Sus scrofa L.) and domestic pigs (Sus scrofa domesticus, Landrace $\times$ Large White) in a semi-extensive production system. J Agric Sci. 2017;155(10):1659. https://doi.org/10.1017/S002185961700065X.

109. Gantuya B, Biró M, Molnár Á, Avar Á, Sharifian Bahraman A, Babai D, Molnár Z. How Mongolian herders perceive ecological change in a "stable" landscape. Ecol Soc. 2021. https://doi.org/10.5751/ ES-12454-260221. 
110. Pitikoe S. Basotho herders learn through culture and social interaction. Learn Cult Soc Interact. 2017;13:104-12.

111. Inga B. Reindeer (Rangifer tarandus tarandus) feeding on lichens and mushrooms; traditional ecological knowledge among reindeer herding Sámi in northern Sweden. Rangifer. 2007;27:93-106. https://doi.org/10. 7557/2.27.2.163.

112. Cavalli-Sforza LL, Feldman MW, Chen KH, Dornbusch SM. Theory and observation in cultural transmission. Science. 1982;218(4567):19-27. https://doi.org/10.1126/science.7123211.

113. Zarger RK. Acquisition and transmission of subsistence knowledge by Q'eqchi'Maya in Belize. In: Stepp JR, Wyndham FS, Zarger RK, editors. Ethnobiology and biocultural diversity. Athens: University of Georgia Press; 2002. p. 592-603.

114. Zent S. Processual perspectives on traditional environmental knowledge. In: Roy E, Stephen JL, Sarah EJ, editors. Understanding cultural transmission in anthropology: a critical synthesis. New York and Oxford: Berghahn Books; 2013. p. 213-65.

115. Zent S, López-Zent E. Ethnobotanical convergence, divergence, and change among the Hoti of the Venezuelan Guayana. Adv Econ Bot. 2004:15:37-78.

116. Eyssartier C, Ladio AH, Lozada M. Cultural transmission of traditional knowledge in two populations of north-western Patagonia. J Ethnobiol Ethnomed. 2008;4(1):1-8. https://doi.org/10.1186/1746-4269-4-25.

117. Ruiz-Mallén I, Morsello C, Reyes-García V, De Faria RBM. Children's use of time and traditional ecological learning. A case study in two Amazonian indigenous societies. Learn Individ Differ. 2013;27:213-22. https:// doi.org/10.1016/j.lindif.2012.12.012.

118. Ingold T. From the transmission of representations to the education of attention. In: Whitehouse $\mathrm{H}$, editor. The debated mind: evolutionary psychology versus ethnography. Oxford: Routledge; 2001. p. 113-53.

119. Berkes F. Indigenous ways of knowing and the study of environmental change. J R Soc N Z. 2009;39:151-6. https://doi.org/10.1080/03014 220909510568
120. Watt AS. On the causes of failure of natural regeneration in British oakwoods. J Ecol. 1919;7(3):173-203.

121. Smilaj I. Način uzgoja i iskorišćavanja slavonskih hrastika (Ways of cultivating and using Slavonian oak groves). Šumarski List. 1939;1:25-36.

122. Haraszthy L, editor. Natura 2000 fajok és élőhelyek Magyarországon. Csákvár: Pro Vértes Természetvédelmi Közalapítvány; 2014.

123. Földes J. A legelő-erdők. A legeltetés kérdése Magyarországon ás annak megoldása erdőgazdasági úton. Országos Erdészeti Egyesület, Budapest; 1895. http://eprints.edk.oee.hu/221/.

124. Hamernyik B. A dunaártéri szigeterdők felujitásáról. Erdészeti Lapok. 1913:52(19):831-42.

125. Kőfalusi G. A Duna-ártéri szigeterdők felújításáról. Erdészeti Lapok. 1913;52(22):945-9.

126. Láng G. Az erdei legelő használatának káros következményeiről. Erdészeti Lapok. 1870;9(4):142-6.

127. Stojanović DB, Levanič T, Matović B, Orlović S. Growth decrease and mortality of oak floodplain forests as a response to change of water regime and climate. Eur J For Res. 2015;4:555-67. https://doi.org/10. 1007/s10342-015-0871-5.

128. http3: Forest Pigs with a Permaculture Expert. https://www.youtube. com/watch?v=053nJsHvmVo.

129. http4: Pigs in woodland management, http://www.calu.bangor.ac.uk/ Technical\%20leaflets/050203Pigsinwoodlandmanagement.pdf.

130. Massei G, Genov PV, Staines BW. The environmental impact of wild boar. Galemys. 2004;16:135-45.

131. Bartha D. Történeti erdőhasználatok Magyarországon. Magyar Tud. 2003:12:1566-77

\section{Publisher's Note}

Springer Nature remains neutral with regard to jurisdictional claims in published maps and institutional affiliations.
Ready to submit your research? Choose BMC and benefit from:

- fast, convenient online submission

- thorough peer review by experienced researchers in your field

- rapid publication on acceptance

- support for research data, including large and complex data types

- gold Open Access which fosters wider collaboration and increased citations

- maximum visibility for your research: over $100 \mathrm{M}$ website views per year

At $\mathrm{BMC}$, research is always in progress.

Learn more biomedcentral.com/submissions 